\title{
Inactive supply wells as conduits for flow and contaminant migration: conditions of occurrence and suggestions for management
}

\author{
Robert M. Gailey ${ }^{1}$ \\ Received: 16 November 2016 / Accepted: 27 March 2017 /Published online: 15 May 2017 \\ (C) The Author(s) 2017. This article is an open access publication
}

\begin{abstract}
Water supply wells can act as conduits for vertical flow and contaminant migration between water-bearing strata under common hydrogeologic and well construction conditions. While recognized by some for decades, there is little published data on the magnitude of flows and extent of resulting water quality impacts. Consequently, the issue may not be acknowledged widely enough and the need for better management persists. This is especially true for unconsolidated alluvial groundwater basins that are hydrologically stressed by agricultural activities. Theoretical and practical considerations indicate that significant water volumes can migrate vertically through wells. The flow is often downward, with shallow groundwater, usually poorer in quality, migrating through conduit wells to degrade deeper water quality. Field data from locations in California, USA, are presented in combination with modeling results to illustrate both the prevalence of conditions conducive to intraborehole flow and the resulting impacts to water quality. Suggestions for management of planned wells include better enforcement of current regulations and more detailed consideration of hydrogeologic conditions during design and installation. A potentially greater management challenge is presented by the large number of existing wells. Monitoring for evidence of conduit flow and solute transport in areas of high well density is recommended to identify wells that pose greater risks to water quality. Conduit wells that are discovered may be addressed through approaches that include structural modification and changes in operations.
\end{abstract}

Robert M. Gailey

rmgailey@ucdavis.edu

1 Department of Civil and Environmental Engineering, University of California Davis, 2001 Ghausi Hall, 1 Shields Avenue,

Davis, CA 95616, USA
Keywords Wellbore leakage · Groundwater flow · Contamination $\cdot$ Corrective measures

\section{Introduction}

It has long been known that vertical flow and contaminant migration can occur through inactive water supply wells when they interconnect water-bearing zones with different hydraulic heads and water qualities-Johnson (1961); California Department of Water Resources (CADWR 1962); Davis et al. (1964). Observations of flow include (1) the sound of water cascading down well screens located above standing water levels (Davis et al. 1964) and (2) downhole videos showing particles entrained in water moving swiftly within well casings and across well screens (observations and consulting reports by field hydrogeologists including the author) as well as measurements of vertical flows through casings (McCombs and Fiedler 1927; Davis et al. 1964). Evidence of contaminant migration includes wells that must be pumped to waste after periods of inactivity in order to reestablish acceptable water quality (Mayo 2010). Such flow and transport can also occur in abandoned supply wells (Gass et al. 1977) as well as improperly destroyed wells (CADWR 1981). While some research and publication on intraborehole flow and transport has occurred, relatively little of the available field data has been documented beyond private reports to well owners and only a few detailed case studies support research findings. Consequently, the prevalence of groundwater supply wells acting as vertical conduits and the extent to which water quality impacts stem from this phenomenon may not be widely understood.

Given the significant reliance on groundwater both globally (Wada et al. 2012) and in specific areas such as California (CADWR 2014), effective resource management should 
include an understanding of the threat to water quality posed by wells that act as conduits. If the threat is appreciated at a sufficiently high regulatory level, approaches to minimize groundwater flow and the spread of contaminants through inactive, abandoned and improperly destroyed wells may be further developed. This work (1) quantifies the effects of intraborehole flow and transport through inactive wells in unconsolidated alluvial groundwater basins and (2) suggests management approaches for reducing impacts. As discussed in the following section, these contributions will add to a developing body of knowledge regarding wells that act as conduits with results from field investigation for several wells in California, USA (Fig. 1).

\section{Previous research}

Table 1 summarizes research on water supply wells acting as vertical conduits. Both flow and contaminant transport are addressed in most cases. Many contributions are theoretical modeling studies. Some include modeling and field data while others evaluate field data without modeling. The MODFLOW Multi-Node Well package (Halford and Hanson 2002; Konikow et al. 2009) was used for many of the studies that model intraborehole flow (Hanson et al. 2004; Konikow and Hornberger 2006; Zinn and Konikow 2007; Clark et al. 2008; Johnson et al. 2011; Yager and Heywood 2014) although some researchers represented flow through the inside of the well casing with an equivalent porous medium (Lacombe et al. 1995; Mejia et al. 2012). Some works consider a small spatial scale (the well and immediate vicinity), while others focus on larger areas (wellfields and regions). The locations of most field examples are in the USA. The hydrogeology consists of sedimentary basins in all but one case and unconsolidated sediments in all but four cases; of 27 citations, there are 16 unique field sites.

Theoretical considerations of intraborehole flow include Sokol (1963) who developed an analytical representation of steady-state flow between multiple confined aquifers. Silliman and Higgins (1990) later developed an analytical approach for representing steady-state flow between two aquifers that included head loss across the well screens and allowed the shallower water-bearing zone to be unconfined. Lacombe et al. (1995) developed a numerical approach to simulate transient flow and solute transport across an aquitard via a leaky borehole under a variety of conditions. The authors concluded that rapid migration and widespread distribution of contamination are possible and the potential impacts of leaky boreholes on groundwater quality should be further evaluated. Konikow and Hornberger (2006) addressed flow and solute transport through hypothetical wells to consider potential effects on groundwater systems. Their results indicated that, under some conditions, intraborehole

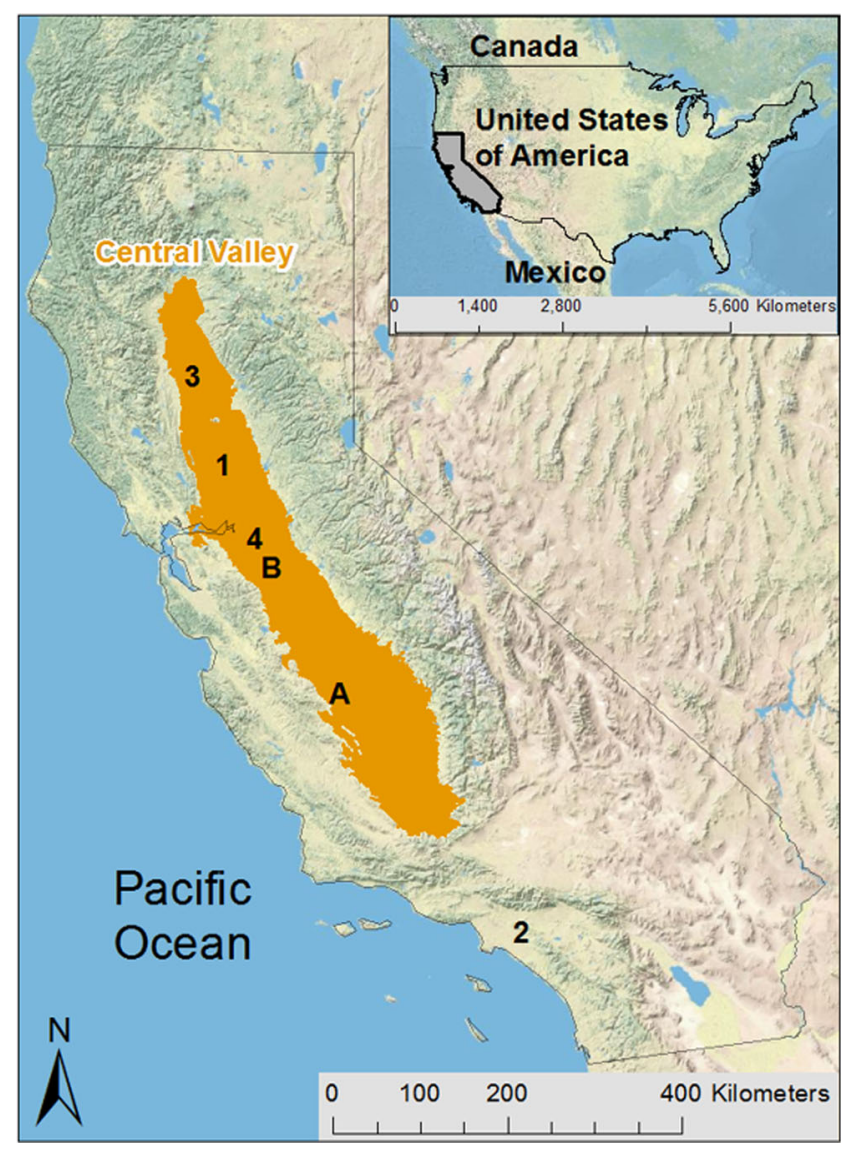

Fig. 1 Study locations in California, USA. Black letters indicate approximate locations of field sites cited in the literature review. Black numbers indicate approximate locations of case examples

flow can occur even when the well is pumped. Zinn and Konikow (2007) explored the effects of intraborehole flow on groundwater age in a hypothetical regional system. They demonstrated that the location of a conduit well in a flow system can determine direction of flow (upwards or downwards) and the depth where age changes as a result of the flow. Changes in pumping stresses within the groundwater system also affected direction and magnitude of flow in conduit wells as well as the depth of impact by transport. Johnson et al. (2011) reinforced the conclusions of others noting that (1) proximity to pumping wells as well as seasonality of pumping influenced the magnitude of vertical flows and (2) bypassing transport through both shallow waterbearing zones and lower hydraulic conductivity sediments reduced protection to deeper groundwater since less solute attenuation occurred.

Early field research documented flow at the well scale. McCombs and Fiedler (1927) may provide the earliest documented measurements of intraborehole flows. The most extensive dataset on vertical flows through inactive water supply wells may be by Davis et al. (1964). They presented ambient flow (well not pumping) data, collected as a profile along the well length with an impeller flowmeter, from 11 idle 
Table 1 Research contributions regarding water supply wells acting as vertical conduits for flow and contaminant migration

\begin{tabular}{|c|c|c|c|c|c|c|c|c|}
\hline \multirow[t]{2}{*}{ Reference } & \multicolumn{2}{|l|}{ Scope } & \multicolumn{2}{|l|}{ Scale } & \multicolumn{2}{|c|}{ Processes } & \multicolumn{2}{|l|}{ Setting } \\
\hline & Theoretical & $\begin{array}{l}\text { Field } \\
\text { data }\end{array}$ & Well & Regional & Flow & Transport & Location & Geology \\
\hline Bexfield et al. 2012 & - & $\mathrm{x}$ & $\mathrm{x}$ & $\mathrm{x}$ & $\mathrm{x}$ & $\mathrm{x}$ & Albuquerque, New Mexico & Unconsol. alluvial \\
\hline \multirow[t]{2}{*}{ Bexfield and Jurgens 2014} & - & $\mathrm{x}$ & $\mathrm{x}$ & $\mathrm{x}$ & $\mathrm{x}$ & $\mathrm{x}$ & Modesto, California, USA & Unconsol. alluvial \\
\hline & - & $\mathrm{x}$ & $\mathrm{x}$ & $\mathrm{x}$ & $\mathrm{x}$ & $\mathrm{x}$ & Albuquerque, New Mexico & Unconsol. alluvial \\
\hline Clark et al. 2008 & - & $\mathrm{x}$ & $\mathrm{x}$ & $\mathrm{x}$ & $\mathrm{x}$ & $\mathrm{x}$ & York, Nebraska, USA & Unconsol. alluvial \\
\hline $\begin{array}{l}\text { Corcho Alvarado et al. } \\
2009\end{array}$ & - & $\mathrm{x}$ & $\mathrm{x}$ & - & $\mathrm{x}$ & $\mathrm{x}$ & Paris Basin, France & Consol. sedimentary \\
\hline Davis et al. 1964 & - & $\mathrm{x}$ & $\mathrm{x}$ & - & $\mathrm{x}$ & - & $\begin{array}{l}\text { San Joaquin Valley, California, } \\
\text { USA }\end{array}$ & Unconsol. alluvial \\
\hline Dragon et al. 2009 & - & $\mathrm{x}$ & $\mathrm{x}$ & $\mathrm{x}$ & $\mathrm{x}$ & $\mathrm{x}$ & Wielkopolska, Poland & Glacio-fluvial and fluvial \\
\hline Hanson et al. 2004 & - & $\mathrm{x}$ & - & $\mathrm{x}$ & $\mathrm{x}$ & - & $\begin{array}{l}\text { Santa Clara Valley, California, } \\
\text { USA }\end{array}$ & Unconsol. alluvial \\
\hline Hart et al. 2006 & - & $\mathrm{x}$ & - & $\mathrm{x}$ & $\mathrm{x}$ & - & Southeastern Wisconsin, USA & Consol. sedimentary \\
\hline $\begin{array}{l}\text { Jiménez-Martínez et al. } \\
2011\end{array}$ & - & $\mathrm{x}$ & - & $\mathrm{x}$ & $\mathrm{x}$ & $\mathrm{x}$ & Campo de Cartagena, Spain & Consol. sedimentary \\
\hline Johnson et al. 2011 & $\mathrm{x}$ & - & $\mathrm{x}$ & $\mathrm{x}$ & $\mathrm{x}$ & - & - & $\begin{array}{l}\text { Multi-layered porous } \\
\text { medium }\end{array}$ \\
\hline Jurgens et al. 2008 & - & $\mathrm{x}$ & $\mathrm{x}$ & $\mathrm{x}$ & $\mathrm{x}$ & $\mathrm{x}$ & Modesto, California, USA & Unconsol. alluvial \\
\hline Jurgens et al. 2014 & - & $\mathrm{x}$ & $\mathrm{x}$ & $\mathrm{x}$ & $\mathrm{x}$ & $\mathrm{x}$ & Albuquerque, New Mexico & Unconsol. alluvial \\
\hline $\begin{array}{l}\text { Konikow and Hornberger } \\
2006\end{array}$ & $\mathrm{x}$ & - & $\mathrm{x}$ & $\mathrm{x}$ & $\mathrm{x}$ & $\mathrm{x}$ & - & $\begin{array}{l}\text { Multi-layered porous } \\
\text { medium }\end{array}$ \\
\hline Lacombe et al. 1995 & $\mathrm{x}$ & - & $\mathrm{x}$ & $\mathrm{x}$ & $\mathrm{x}$ & $\mathrm{x}$ & - & $\begin{array}{l}\text { Multi-layered porous } \\
\text { medium }\end{array}$ \\
\hline Landon et al. 2008 & - & $\mathrm{x}$ & $\mathrm{x}$ & $\mathrm{x}$ & $\mathrm{x}$ & $\mathrm{x}$ & York, Nebraska, USA & Unconsol. alluvial \\
\hline \multirow[t]{2}{*}{ Landon et al. 2009} & - & $\mathrm{x}$ & $\mathrm{x}$ & $\mathrm{x}$ & $\mathrm{x}$ & $\mathrm{x}$ & Modesto, California, USA & Unconsol. alluvial \\
\hline & - & $\mathrm{x}$ & $\mathrm{x}$ & $\mathrm{x}$ & $\mathrm{x}$ & $\mathrm{x}$ & York, Nebraska, USA & Unconsol. alluvial \\
\hline Lu et al. 2008 & - & $\mathrm{x}$ & - & $\mathrm{x}$ & $\mathrm{x}$ & $\mathrm{x}$ & Chianan Plain, Taiwan & Unconsol. near-shore \\
\hline Mayo 2010 & - & $\mathrm{x}$ & $\mathrm{x}$ & - & $\mathrm{x}$ & $\mathrm{x}$ & $\begin{array}{l}\text { San Luis Valley, Colorado, } \\
\text { USA }\end{array}$ & $\begin{array}{l}\text { Unconsol. Lacustrine } \\
\text { and fluvial }\end{array}$ \\
\hline \multirow[t]{2}{*}{ McCombs and Fiedler 1927} & - & $\mathrm{x}$ & $\mathrm{x}$ & - & $\mathrm{x}$ & - & Oahu, Hawaii, USA & Vesicular basalt \\
\hline & - & $\mathrm{x}$ & $\mathrm{x}$ & - & $\mathrm{x}$ & - & $\begin{array}{l}\text { Pecos Valley, New Mexico, } \\
\text { USA }\end{array}$ & Consol. sedimentary \\
\hline Mejia et al. 2012 & $\mathrm{x}$ & - & $\mathrm{x}$ & $\mathrm{x}$ & $\mathrm{x}$ & $\mathrm{x}$ & - & $\begin{array}{l}\text { Multi-layered porous } \\
\text { medium }\end{array}$ \\
\hline Santi et al. 2006 & - & $\mathrm{x}$ & - & $\mathrm{x}$ & $\mathrm{x}$ & $\mathrm{x}$ & Merced, California, USA & Unconsol. alluvial \\
\hline Silliman and Higgins 1990 & $\mathrm{x}$ & - & $\mathrm{x}$ & - & $\mathrm{x}$ & - & - & $\begin{array}{l}\text { Multi-layered porous } \\
\text { medium }\end{array}$ \\
\hline Sokol 1963 & $\mathrm{x}$ & - & $\mathrm{x}$ & - & $\mathrm{x}$ & - & - & $\begin{array}{l}\text { Multi-layered porous } \\
\text { medium }\end{array}$ \\
\hline \multirow[t]{2}{*}{ Viers et al. 2012} & $\mathrm{x}$ & $\mathrm{x}$ & - & $\mathrm{x}$ & $\mathrm{x}$ & $\mathrm{x}$ & $\begin{array}{l}\text { San Joaquin Valley, California, } \\
\text { USA }\end{array}$ & Unconsol. alluvial \\
\hline & $\mathrm{x}$ & $\mathrm{x}$ & - & $\mathrm{x}$ & $\mathrm{x}$ & $\mathrm{x}$ & Salinas Valley, California, USA & Unconsol. alluvial \\
\hline Williamson et al. 1989 & - & $\mathrm{x}$ & - & $\mathrm{x}$ & $\mathrm{x}$ & - & Central Valley, California, USA & Unconsol. alluvial \\
\hline \multirow[t]{2}{*}{ Yager and Heywood 2014} & - & $\mathrm{x}$ & $\mathrm{x}$ & - & $\mathrm{x}$ & $\mathrm{x}$ & Modesto, California, USA & Unconsol. alluvial \\
\hline & - & $\mathrm{x}$ & $\mathrm{x}$ & - & $\mathrm{x}$ & $\mathrm{x}$ & Albuquerque, New Mexico & Unconsol. alluvial \\
\hline Zinn and Konikow 2007 & $\mathrm{x}$ & - & $\mathrm{x}$ & $\mathrm{x}$ & $\mathrm{x}$ & $\mathrm{x}$ & - & $\begin{array}{l}\text { Multi-layered porous } \\
\text { medium }\end{array}$ \\
\hline
\end{tabular}

agricultural supply wells located in the western San Joaquin Valley of California (see A on Fig. 1 for location and Table 2 for data). The wells penetrated the deeper water-bearing zone beneath a regional aquitard (Corcoran Clay). Flow measurements ranged from 48 to $478 \mathrm{gal} / \mathrm{min}$, or $187-1,852 \mathrm{l} / \mathrm{min}$, at depths within the range of $485-1,350 \mathrm{ft}$ below ground surface 
Table 2 Flow profiling conducted by Davis et al. 1964 . Kinematic viscosity used to calculate Reynolds numbers: $1.1092 \mathrm{~mm} / \mathrm{s}$ at $16^{\circ} \mathrm{C}$

\begin{tabular}{|c|c|c|c|c|c|c|c|c|c|c|}
\hline \multirow[t]{3}{*}{ Well number } & \multirow{3}{*}{$\begin{array}{l}\text { Screened } \\
\text { interval } \\
\text { (bgs) }\end{array}$} & \multicolumn{5}{|c|}{ Conduit flow } & \multirow{2}{*}{\multicolumn{2}{|c|}{ Well diameter }} & \multirow{2}{*}{$\begin{array}{l}\text { Flow } \\
\text { velocity }\end{array}$} & \multirow{2}{*}{$\begin{array}{l}\text { Reynolds } \\
\text { number }^{\mathrm{a}}\end{array}$} \\
\hline & & \multicolumn{2}{|l|}{ Depth } & \multicolumn{2}{|c|}{ Cumulative } & \multirow{2}{*}{$\begin{array}{l}\text { Incremental } \\
(1 / \mathrm{min})\end{array}$} & & & & \\
\hline & & (ft bgs) & (m bgs) & $(\mathrm{cfs})$ & $(1 / \min )$ & & (in) & $(\mathrm{cm})$ & $(\mathrm{m} / \mathrm{s})$ & $(-)$ \\
\hline \multirow[t]{10}{*}{ 14/12-12 N1 } & \multirow{10}{*}{$\begin{array}{l}558-1,709 \mathrm{ft} \\
(170-521 \mathrm{~m})\end{array}$} & 550 & 168 & 0.00 & 0 & 0 & 12.75 & 32 & 0.00 & $0.0 \mathrm{E}+00$ \\
\hline & & 600 & 183 & 0.20 & 340 & 340 & 12.75 & 32 & 0.07 & $2.0 \mathrm{E}+04$ \\
\hline & & 650 & 198 & 0.23 & 391 & 51 & 12.75 & 32 & 0.08 & $2.3 \mathrm{E}+04$ \\
\hline & & 700 & 213 & 0.13 & 221 & -170 & 12.75 & 32 & 0.04 & $1.3 \mathrm{E}+04$ \\
\hline & & 800 & 244 & 0.16 & 272 & 51 & 12.75 & 32 & 0.06 & $1.6 \mathrm{E}+04$ \\
\hline & & 900 & 274 & 0.12 & 204 & -68 & 10.75 & 27 & 0.06 & $1.4 \mathrm{E}+04$ \\
\hline & & 1,000 & 305 & 0.19 & 323 & 119 & 10.75 & 27 & 0.09 & $2.3 \mathrm{E}+04$ \\
\hline & & 1,100 & 335 & 0.16 & 272 & -51 & 10.75 & 27 & 0.08 & $1.9 \mathrm{E}+04$ \\
\hline & & 1,200 & 366 & 0.16 & 272 & 0 & 10.75 & 27 & 0.08 & $1.9 \mathrm{E}+04$ \\
\hline & & 1,300 & 396 & 0.11 & 187 & -85 & 10.75 & 27 & 0.05 & $1.3 \mathrm{E}+04$ \\
\hline \multirow[t]{9}{*}{ 14/13-17 E1 } & \multirow[t]{9}{*}{ Unknown } & 600 & 183 & 0.00 & 0 & 0 & 18.00 & 46 & 0.00 & $0.0 \mathrm{E}+00$ \\
\hline & & 700 & 213 & 0.00 & 0 & 0 & 18.00 & 46 & 0.00 & $0.0 \mathrm{E}+00$ \\
\hline & & 734 & 224 & 0.12 & 204 & 204 & 18.00 & 46 & 0.02 & $8.5 \mathrm{E}+03$ \\
\hline & & 750 & 229 & 0.13 & 221 & 17 & 18.00 & 46 & 0.02 & $9.2 \mathrm{E}+03$ \\
\hline & & 760 & 232 & 0.12 & 204 & -17 & 12.75 & 32 & 0.04 & $1.2 \mathrm{E}+04$ \\
\hline & & 800 & 244 & 0.15 & 255 & 51 & 12.75 & 32 & 0.05 & $1.5 \mathrm{E}+04$ \\
\hline & & 900 & 274 & 0.19 & 323 & 68 & 12.75 & 32 & 0.07 & $1.9 \mathrm{E}+04$ \\
\hline & & 1,000 & 305 & 0.19 & 323 & 0 & 12.75 & 32 & 0.07 & $1.9 \mathrm{E}+04$ \\
\hline & & 1,100 & 335 & 0.00 & 0 & -323 & 12.75 & 32 & 0.00 & $0.0 \mathrm{E}+00$ \\
\hline \multirow[t]{4}{*}{ 14/13-29 Q1 } & & 800 & 244 & 0.00 & 0 & 0 & 12.75 & 32 & 0.00 & $0.0 \mathrm{E}+00$ \\
\hline & \multirow{3}{*}{$(189-550 \mathrm{~m})$} & 900 & 274 & 0.12 & 204 & 204 & 12.75 & 32 & 0.04 & $1.2 \mathrm{E}+04$ \\
\hline & & 1,000 & 305 & 0.14 & 238 & 34 & 10.75 & 27 & 0.07 & $1.7 \mathrm{E}+04$ \\
\hline & & 1,050 & 320 & 0.18 & 306 & 68 & 10.75 & 27 & 0.09 & $2.1 \mathrm{E}+04$ \\
\hline \multirow[t]{6}{*}{ 15/13-8 N1 } & $639-1,798 \mathrm{ft}$ & 650 & 198 & 0.00 & 0 & 0 & 12.75 & 32 & 0.00 & $0.0 \mathrm{E}+00$ \\
\hline & \multirow[t]{5}{*}{$(195-548 \mathrm{~m})$} & 675 & 206 & 0.49 & 832 & 832 & 12.75 & 32 & 0.17 & $4.9 \mathrm{E}+04$ \\
\hline & & 707 & 215 & 0.44 & 747 & -85 & 12.75 & 32 & 0.15 & $4.4 \mathrm{E}+04$ \\
\hline & & 750 & 229 & 0.44 & 747 & 0 & 12.75 & 32 & 0.15 & $4.4 \mathrm{E}+04$ \\
\hline & & 800 & 244 & 0.47 & 798 & 51 & 12.75 & 32 & 0.16 & $4.7 \mathrm{E}+04$ \\
\hline & & 1,000 & 305 & 0.47 & 798 & 0 & 10.75 & 27 & 0.23 & $5.6 \mathrm{E}+04$ \\
\hline \multirow[t]{5}{*}{$16 / 15-26 \mathrm{~N} 3$} & \multirow[t]{5}{*}{ Unknown } & 700 & 213 & 0.00 & 0 & 0 & 12.75 & 32 & 0.00 & $0.0 \mathrm{E}+00$ \\
\hline & & 800 & 244 & 0.00 & 0 & 0 & 12.75 & 32 & 0.00 & $0.0 \mathrm{E}+00$ \\
\hline & & 910 & 277 & 0.19 & 323 & 323 & 12.75 & 32 & 0.07 & $1.9 \mathrm{E}+04$ \\
\hline & & 1,000 & 305 & 0.26 & 442 & 119 & 12.75 & 32 & 0.09 & $2.6 \mathrm{E}+04$ \\
\hline & & 1,100 & 335 & 0.00 & 0 & -442 & 12.75 & 32 & 0.00 & $0.0 \mathrm{E}+00$ \\
\hline \multirow[t]{6}{*}{ 17/15-27 K1 } & $912-2,130 \mathrm{ft}$ & 925 & 282 & 0.00 & 0 & 0 & 12.75 & 32 & 0.00 & $0.0 \mathrm{E}+00$ \\
\hline & $(278-649 \mathrm{~m})$ & 975 & 297 & 0.18 & 306 & 306 & 12.75 & 32 & 0.06 & $1.8 \mathrm{E}+04$ \\
\hline & & 1,025 & 312 & 0.48 & 815 & 510 & 12.75 & 32 & 0.17 & $4.8 \mathrm{E}+04$ \\
\hline & & 1,100 & 335 & 0.48 & 815 & 0 & 10.75 & 27 & 0.23 & $5.7 \mathrm{E}+04$ \\
\hline & & 1,200 & 366 & 0.48 & 815 & 0 & 10.75 & 27 & 0.23 & $5.7 \mathrm{E}+04$ \\
\hline & & 1,300 & 396 & 0.48 & 815 & 0 & 10.75 & 27 & 0.23 & $5.7 \mathrm{E}+04$ \\
\hline 17/16-4 E1 & $416-1,580 \mathrm{ft}$ & 475 & 145 & 0.00 & 0 & 0 & 10.75 & 27 & 0.00 & $0.0 \mathrm{E}+00$ \\
\hline & $(127-482 \mathrm{~m})$ & 485 & 148 & 0.54 & 917 & 917 & 10.75 & 27 & 0.26 & $6.4 \mathrm{E}+04$ \\
\hline & & 500 & 152 & 0.36 & 612 & -306 & 10.75 & 27 & 0.17 & $4.3 \mathrm{E}+04$ \\
\hline & & 525 & 160 & 0.46 & 781 & 170 & 10.75 & 27 & 0.22 & $5.5 \mathrm{E}+04$ \\
\hline & & 549 & 167 & 1.09 & 1852 & 1070 & 10.75 & 27 & 0.53 & $1.3 \mathrm{E}+05$ \\
\hline
\end{tabular}


Table 2 (continued)

\begin{tabular}{|c|c|c|c|c|c|c|c|c|c|c|}
\hline \multirow[t]{3}{*}{ Well number } & \multirow{3}{*}{$\begin{array}{l}\text { Screened } \\
\text { interval } \\
\text { (bgs) }\end{array}$} & \multicolumn{5}{|c|}{ Conduit flow } & \multirow{2}{*}{\multicolumn{2}{|c|}{ Well diameter }} & \multirow{2}{*}{$\begin{array}{l}\text { Flow } \\
\text { velocity }\end{array}$} & \multirow{2}{*}{$\begin{array}{l}\text { Reynolds } \\
\text { number }^{\mathrm{a}}\end{array}$} \\
\hline & & \multicolumn{2}{|l|}{ Depth } & \multicolumn{2}{|c|}{ Cumulative } & \multirow{2}{*}{$\begin{array}{l}\text { Incremental } \\
(1 / \mathrm{min})\end{array}$} & & & & \\
\hline & & (ft bgs) & (m bgs) & $(\mathrm{cfs})$ & $(1 / \mathrm{min})$ & & (in) & $(\mathrm{cm})$ & $(\mathrm{m} / \mathrm{s})$ & $(-)$ \\
\hline & & 600 & 183 & 0.96 & 1631 & -221 & 10.75 & 27 & 0.46 & $1.1 \mathrm{E}+05$ \\
\hline \multirow[t]{8}{*}{ 17/16-8 L1 } & $553-1,800 \mathrm{ft}$ & 550 & 168 & 0.00 & 0 & 0 & 12.75 & 32 & 0.00 & $0.0 \mathrm{E}+00$ \\
\hline & $(169-549 \mathrm{~m})$ & 650 & 198 & 0.54 & 917 & 917 & 12.75 & 32 & 0.19 & $5.4 \mathrm{E}+04$ \\
\hline & & 700 & 213 & 0.14 & 238 & -679 & 12.75 & 32 & 0.05 & $1.4 \mathrm{E}+04$ \\
\hline & & 800 & 244 & 0.13 & 221 & -17 & 12.75 & 32 & 0.04 & $1.3 \mathrm{E}+04$ \\
\hline & & 900 & 274 & 0.27 & 459 & 238 & 12.75 & 32 & 0.09 & $2.7 E+04$ \\
\hline & & 1,000 & 305 & 0.20 & 340 & -119 & 12.75 & 32 & 0.07 & $2.0 \mathrm{E}+04$ \\
\hline & & 1,100 & 335 & 0.16 & 272 & -68 & 12.75 & 32 & 0.06 & $1.6 \mathrm{E}+04$ \\
\hline & & 1,200 & 366 & 0.00 & 0 & -272 & 10.75 & 27 & 0.00 & $0.0 \mathrm{E}+00$ \\
\hline \multirow[t]{4}{*}{ 19/17-19 D1 } & $721-2,063 \mathrm{ft}$ & 700 & 213 & 0.00 & 0 & 0 & 12.75 & 32 & 0.00 & $0.0 \mathrm{E}+00$ \\
\hline & $(220-629 \mathrm{~m})$ & 800 & 244 & 0.12 & 204 & 204 & 12.75 & 32 & 0.04 & $1.2 \mathrm{E}+04$ \\
\hline & & 900 & 274 & 0.12 & 204 & 0 & 12.75 & 32 & 0.04 & $1.2 \mathrm{E}+04$ \\
\hline & & 1,000 & 305 & 0.00 & 0 & -204 & 12.75 & 32 & 0.00 & $0.0 \mathrm{E}+00$ \\
\hline \multirow[t]{5}{*}{ 19/17-19 P1 } & $665-2,030 \mathrm{ft}$ & 400 & 122 & 0.00 & 0 & 0 & 16.00 & 41 & 0.00 & $0.0 \mathrm{E}+00$ \\
\hline & $(203-619 \mathrm{~m})$ & 450 & 137 & 0.51 & 866 & 866 & 16.00 & 41 & 0.11 & $4.1 E+04$ \\
\hline & & 700 & 213 & 0.21 & 357 & -510 & 12.75 & 32 & 0.07 & $2.1 \mathrm{E}+04$ \\
\hline & & 900 & 274 & 0.16 & 272 & -85 & 12.75 & 32 & 0.06 & $1.6 \mathrm{E}+04$ \\
\hline & & 1,100 & 335 & 0.16 & 272 & 0 & 10.75 & 27 & 0.08 & $1.9 \mathrm{E}+04$ \\
\hline \multirow[t]{11}{*}{ 19/18-33 N2 } & $632-2,025 \mathrm{ft}$ & 575 & 175 & 0.00 & 0 & 0 & 16.00 & 41 & 0.00 & $0.0 \mathrm{E}+00$ \\
\hline & $(193-617 \mathrm{~m})$ & 600 & 183 & 0.00 & 0 & 0 & 16.00 & 41 & 0.00 & $0.0 \mathrm{E}+00$ \\
\hline & & 625 & 191 & 0.42 & 713 & 713 & 16.00 & 41 & 0.09 & $3.4 \mathrm{E}+04$ \\
\hline & & 650 & 198 & 0.47 & 798 & 85 & 12.75 & 32 & 0.16 & $4.7 \mathrm{E}+04$ \\
\hline & & 750 & 229 & 0.40 & 679 & -119 & 12.75 & 32 & 0.14 & $4.0 \mathrm{E}+04$ \\
\hline & & 850 & 259 & 0.38 & 646 & -34 & 12.75 & 32 & 0.13 & $3.8 \mathrm{E}+04$ \\
\hline & & 950 & 290 & 0.38 & 646 & 0 & 12.75 & 32 & 0.13 & $3.8 \mathrm{E}+04$ \\
\hline & & 1,050 & 320 & 0.43 & 730 & 85 & 12.75 & 32 & 0.15 & $4.3 E+04$ \\
\hline & & 1,150 & 351 & 0.39 & 662 & -68 & 12.75 & 32 & 0.13 & $3.9 E+04$ \\
\hline & & 1,240 & 378 & 0.38 & 646 & -17 & 12.75 & 32 & 0.13 & $3.8 \mathrm{E}+04$ \\
\hline & & 1,350 & 411 & 0.37 & 629 & -17 & 12.75 & 32 & 0.13 & $3.7 \mathrm{E}+04$ \\
\hline
\end{tabular}

Data for Screened interval, Conduit flow (including Depth and Cumulative) and Well diameter are as presented by Davis et al. (1964). Data for Incremental conduit flows, Flow velocity, Reynolds number and entries in columns with headings that include SI units are calculated from those by the author

$f t$ bgs feet below ground surface; $m$ bgs meters below ground surface; $c f s$ cubic feet per second; $l / m i n$ liters per minute; in inches; $c m$ centimeters; $\mathrm{m} / \mathrm{s}$ meters per second

${ }^{a}$ Reynolds number values greater than $2.1 \mathrm{E}+03$ in pipes indicate departures from laminar flow (Vennard and Street 1982)

(ft bgs), or 148-411 m below ground surface (m bgs). Flow profiles increased with depth in the wells as groundwater entered the wells, largely through holes in the casing, and decreased as water exited the wells through the screen perforations. As indicated by the Reynolds numbers, turbulent flow occurred in the wells. The authors noted that the observed intraborehole flow rates were consistent with intensive groundwater pumping for agricultural irrigation that occurred throughout the groundwater system for years before the data were collected. In this area, pumping from depth and return flows from irrigation at the ground surface created vertical head differences as great as $300 \mathrm{ft}(91 \mathrm{~m})$ that drove flow down through the wells.

More recent research documented and evaluated well-scale transport occurring in the field. Corcho Alvarado et al. (2009) analyzed vertical profile data for tritium activity and temperature from an inactive long-screened supply well in an area where downward vertical hydraulic gradients were anticipated and found that the results were consistent with intraborehole transport. Landon et al. (2009) concluded that a long-screened 
public supply well in Modesto, California (B on Fig. 1) acted as a conduit partly based on (1) local downward vertical hydraulic gradients and (2) correlation between periods of pump inactivity and concentration increases in deeper water-bearing zones of constituents typically found in shallow water-bearing zones. Bexfield et al. (2012), Bexfield and Jurgens (2014), Jurgens et al. (2008) and (2014) documented vertical groundwater flow and contaminant migration through municipal supply wells in two different parts of USA (Modesto, California and Albuquerque, New Mexico) during periods of nonoperation. Ambient flow was downwards in one well and upwards in the other. Effects on water quality, including elevated arsenic, nitrate and uranium concentrations, changed seasonally with vertical hydraulic gradients. The authors indicated the potential for similar occurrences in other alluvial basins with stratified water quality and vertical hydraulic gradients. Yager and Heywood (2014) modeled these two wells and showed that flow and contaminant migration during nonoperation degraded water quality. They showed that pumping during the off-season could reduce the undesired flows and water quality degradation but noted that the costs of the additional pumping should be weighed against costs of other options such as structurally modifying the wells to prevent connection of separate water-bearing strata.

Others have evaluated the effects of flows through inactive wells at the regional scale. For the Central Valley of California, Williamson et al. (1989) estimated through numerical modeling that, in areas where the density of multi-aquifer wells equaled or exceeded one per square mile, the effective vertical hydraulic conductivity of confining layers in the groundwater system could increase by a factor of seven as a result of flow through well casings. Similarly, while modeling the western portion of the San Joaquin Valley, California, Phillips and Belitz (1991) and Belitz et al. (1993) found that the calibrated value for vertical hydraulic conductivity for the regional aquitard was higher than expected from permeameter data and reasoned that flow through the many multi-aquifer wells in the study area was the cause. Bertoldi et al. (1991) and Faunt (2009) provide additional support for these findings. Hanson et al. (2004) modeled groundwater flow in the Santa Clara Valley of California and estimated that approximately $19 \%$ of flow from shallower to deeper strata occurred through wells. Hart et al. (2006) investigated potential flow mechanisms responsible for a discrepancy between core-scale and regional estimates of vertical conductivity for an aquitard in Wisconsin, USA. Using a combination of numerical and analytical modeling, they found that flow through a single well could be approximately $700 \mathrm{l} / \mathrm{min}$ and a spacing of one well every $10 \mathrm{~km}$ would be sufficient to account for the difference in flow implied by the different estimates of hydraulic conductivity. For a public supply well near York, Nebraska, a combination of field and modeling studies indicated that approximately $25 \%$ of the water that migrated from shallow to deeper groundwater crossed the aquitard by flowing directly through wells or boreholes that connected water-bearing strata separated by the aquitard (Clark et al. 2008, Landon et al. 2008, 2009). Viers et al. (2012) and Mejia et al. (2012) evaluated the potential for nitrate migration from shallow groundwater to deeper strata over broad geographic areas using algebraic and numerical modeling methods, respecitvely. The potential effects of intraborehole flow and transport on a regional scale have also been considered in Poland (Dragon et al. 2009), Spain (Jiménez-Martínez et al. 2011) and Taiwan (Lu et al. 2008).

There are three significant limitations of the currently available literature. First, only three studies present actual measurements of intraborehole flow. McCombs and Fiedler (1927) measured a maximum flow equivalent to $520 \mathrm{gal} / \mathrm{min}$ (1970 1/min). Davis et al. (1964) measured a maximum flow rate of $478 \mathrm{gal} / \mathrm{min}(1,852 \mathrm{l} / \mathrm{min})$. Bexfield et al. (2012) measured a maximum flow rate of $204 \mathrm{gal} / \mathrm{min}(772 \mathrm{l} / \mathrm{min})$. Second, only one study presents information regarding the extent of water quality impact. Mayo (2010) reported that, after a well had been out of operation for 71 days, reversing the water quality impact from migration of total dissolved solids required running the well at its operational pumping rate of $175 \mathrm{gal} / \mathrm{min}(660 \mathrm{l} / \mathrm{min})$ for approximately 15 days (approximately $3.8 \times 10^{6}$ gal or $14.3 \times 10^{6} 1$ extracted). Third, only one study suggests management approaches. Yager and Heywood (2014) suggested off-season pumping as a possible approach for limiting water quality impacts for specific wells. This current work provides additional field information on intraborehole flow measurements and the extent of water quality impacts as well as suggests several management approaches.

\section{Overview of flow and transport processes}

\section{Conditions when intraborehole flows occur}

Figure 2a depicts a sedimentary groundwater basin with multiple permeable water-bearing zones common in many parts of the world. Vertical head gradients, both upward and downward, will be present in basins as a natural consequence of recharge and discharge (Fetter 1994; Phillips et al. 2007). Downward gradients also can result from hydraulic stresses induced by human activity such as groundwater extraction from deeper strata and deep percolation associated with crop irrigation (Fig. 2b). In alluvial aquifers and other stratified sedimentary groundwater systems, pronounced bulk anisotropy of hydraulic conductivity $\left(K_{\text {vertical }} / K_{\text {horizontal }}\right)$, perhaps on the order of $10^{-3}-10^{-4}$, often limits vertical flow and vertical hydraulic gradients can exceed horizontal gradients by orders of magnitude (Fogg 1986). For conditions that exist in agriculturally stressed alluvial groundwater systems, horizontal 

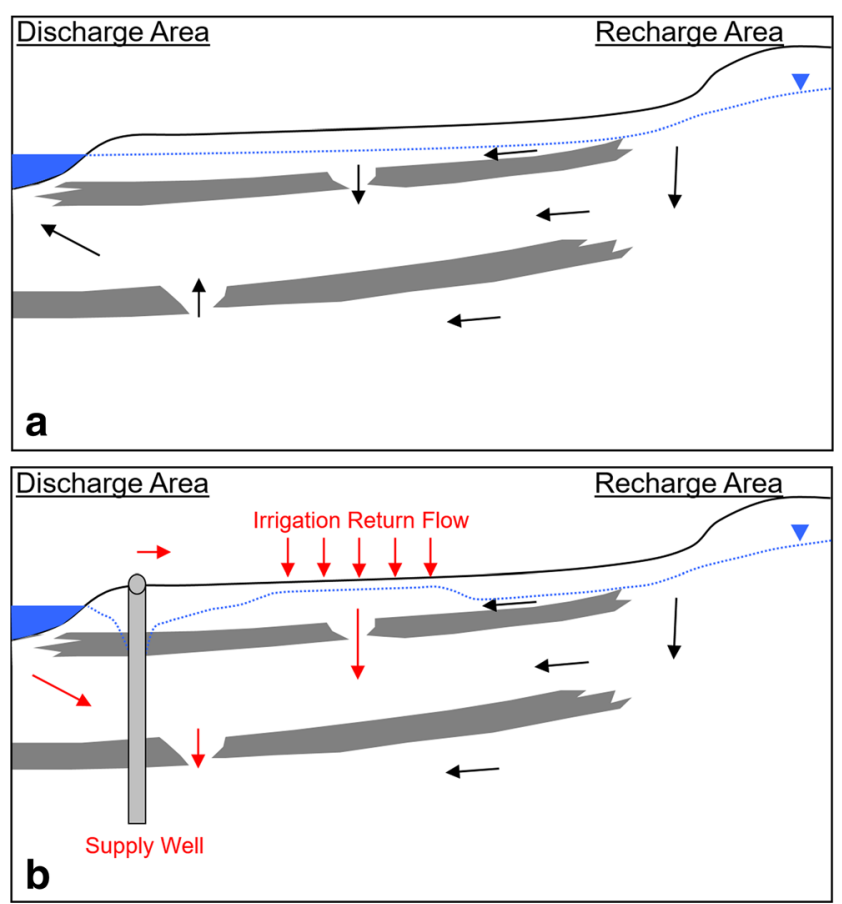

Fig. 2 Simplified depiction of unconsolidated sedimentary groundwater basin: a natural system and $\mathbf{b}$ changes in groundwater stresses and flows from human activities. White areas indicate water-bearing zones. Gray areas indicate aquitards. Spatial variation in hydraulic conductivity within hydrostratigraphic units not shown. Black arrows indicate direction of groundwater flow. Red arrows indicate changes induced by human activities. Blue dotted line and triangle indicate the water table

and vertical hydraulic gradients can be on the order of $10^{-3}$ and $10^{-1}$, respectively (see field examples Nos. 2 and 4 in the following). When an interconnecting vertical pathway exists, the vertical gradients are sustained regionally by the previously referenced hydraulic stresses and drive vertical flows on a continual basis.

Interconnecting vertical pathways may exist naturally within the sedimentary structure (gaps in aquitards from erosion before burial or discontinuities in silts and clays deposited by spatially variable processes) or artificially as a result of well construction. Figure 3 shows a range of common well designs and preferential pathways for groundwater flow when vertical gradients are present. A properly designed and maintained well that provides little potential for vertical flow is depicted at the left of Fig. 3 and serves as a basis for comparison. This well consists of (1) a well casing and screen installed within a borehole, (2) a cement seal filling the annular space between the borehole wall and the well casing that extends from ground surface down into the aquitard, (3) a gravel pack filling the annular space that extends from above the top to below the bottom of the screen and (4) a gravel fill tube for replenishing the gravel pack in the event of any settlement resulting from operations. Common elements that create the potential for wells to act as vertical conduits include long screens, multiple shorter screens separated over long vertical distances and long gravel packs (Santi et al. 2006). Another common well condition leading to a well becoming a vertical conduit is localized failure of the casing or other steel component (tool port or gravel fill tube) from corrosion or failure of a welded joint. Such a failure allows hydraulic communication between shallower and deeper strata separated by relatively long distances through the interior of the well. The term "long" is used within the context of the hydrogeology at a particular well site. Well elements are considered long if they cross hydraulic barriers created by finer-grained strata where differences in hydraulic head occur (see Fig. 3). Conditions that result in flow through the well casing instead of the gravel pack will generally result in higher velocities and larger volumes of water transferred between strata because, as discussed in the following, resistance to flow will be many orders of magnitude less inside the casing.

Consistent with Darcy's Law, the potential magnitude of intraborehole flow depends upon both resistance along the flow path and the hydraulic gradient that drives the flow. Typical vertical hydraulic conductivity values for sediments range from approximately $10^{-7}$ to $10 \mathrm{~cm} / \mathrm{s}$ (Freeze and Cherry 1979; Fetter 1994), while effective pipe conductivities for well casings or screens and gravel fill tubes are much higher at approximately $10^{4}$ to $10^{6} \mathrm{~cm} / \mathrm{s}$. Pipe conductivities may be calculated using the Hagen-Poiseuille equation for assumed laminar flow conditions: $K_{\text {well }}=r^{2} \rho g / 8 \mu$, where $r$ is the inner radius of the well casing or screen, $\rho$ is the fluid density, $g$ is the gravitational acceleration and $\mu$ is the fluid viscosity (Reilly et al. 1989; Lacombe et al. 1995). Because the hydraulic conductivity values for well components are orders of magnitude greater than those for sediments, it is energetically more favorable for water to flow through the well, either the gravelfilled borehole annulus or the open casing, than across the lower hydraulic conductivity strata. The range in vertical hydraulic gradients are discussed in the field examples in the following, but experience suggests that they can be at least as high as -0.8 (see field example No. 2 in the following). As indicated previously and further discussed in the following field examples, flow rates can range up to thousands of liters per minute.

Based on field data, Mayo (2010) found that vertical head differences of $0.1 \mathrm{~m}$ could be significant for intraborehole flow where the higher-head stratum is contaminated; however, even smaller head differences can drive intraborehole flows that are quite high since the effective hydraulic conductivity for a well is many orders of magnitude greater than for a natural porous medium. A head difference of as little as $0.01 \mathrm{~m}$ over a vertical distance of $10 \mathrm{~m}$ would create a vertical gradient on the same order of magnitude as typically observed for horizontal gradients, but the flow through a conduit well would be many orders of magnitude greater than through the natural system given the higher hydraulic conductivity of the well. Because head differences of $0.01 \mathrm{~m}$ are not easily 
Fig. 3 Range of well conditions. Red arrows indicate potential vertical flow pathways. Blue symbols indicate piezometric levels at different depths in the groundwater system

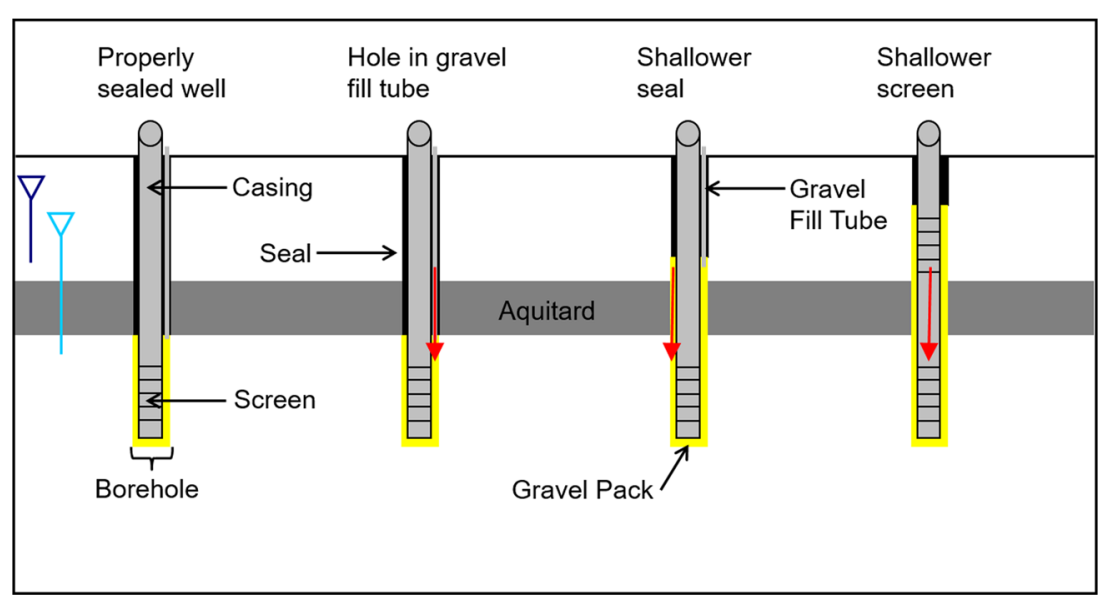

measured in the field, many intraborehole flows may not be apparent unless measurements of flow in the wellbore are made or water quality data are collected over time.

\section{Transport impacts from intraborehole flows}

Areas where flow through wells is investigated are often located in groundwater systems significantly affected by human activities that create or enhance downward gradients. In these areas, shallow water that is also often affected by activities at ground surface and poorer in quality (i.e., nitrate, pesticides and other organic compounds from anthropogenic sources; Burow et al. 2007) migrates downward. Migration through wells bypasses lower hydraulic conductivity sediments and reduces water quality protections afforded by (1) longer travel times of perhaps $100 \mathrm{~s}-1,000 \mathrm{~s}$ of years and (2) beneficial chemical reactions such as denitrification (McMahon et al. 2008). Deeper water quality is degraded in these cases; however, shallow groundwater quality impacts may also occur where flow is upward through wells and deeper strata contain naturally occurring undesirable constituents such as arsenic, chloride or hexavalent chromium (Izbicki et al. 2005a, b, 2006, 2008; Izbicki et al. 2015).

In addition to problems from well construction, well management practices contribute to water quality impacts from vertical flows through wells. Extended well inactivity (months to years) allows ongoing flows to accumulate larger volumes of water and masses of dissolved constituents moving between strata. Irrigation and some municipal supply wells are commonly left inactive each year during the winter when demands decrease. Common naturally occurring constituents that can be mobilized include the inorganic constituents mentioned in the previous as well as dissolved gasses such as oxygen. Anthropogenic constituents that can be mobilized include nitrate, volatile organic compounds, total dissolved solids including chloride, fumigants, pesticides and uranium (if mobilized by changing redox conditions with agricultural irrigation, see Jurgens et al. 2010). When intraborehole flow occurs, contaminated water displaces better quality water at depth when the well is inactive (Fig. 4a). As depicted in Fig. 4b, the quality of produced water then includes a less favorable mix upon restarting the well (Bexfield and Jurgens 2014).

The hydraulic performance of a well can also be reduced by conduit flow and transport. Mixing of geochemically dissimilar waters from different strata often causes precipitation of
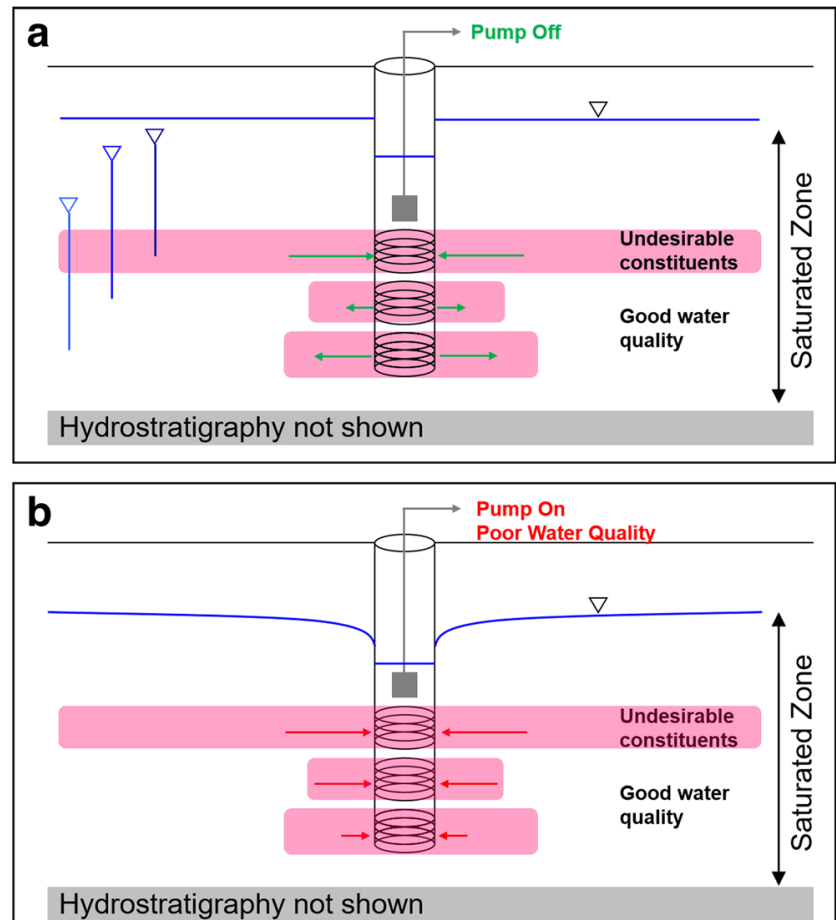

Fig. 4 Schematic of well that acts as a conduit: a vertical flow and contaminant migration through an inactive well (Blue symbols indicate piezometric levels at different depths in the groundwater system) and $\mathbf{b}$ water quality degradation during pumping after contaminant migration through conduit. Lengths of arrows indicate flow magnitudes in a heterogeneous hydraulic conductivity field 
inorganic chemical species that clog well screens (Houben and Treskatis 2007; Van Beek 2012). Oxygenation of deeper waters can spur bacterial growth that also clogs well screens (Mansuy 1999). In both cases, suspended sediment from the aquifer material that is often entrained in the flow can become adhered to well components by the inorganic precipitates and bacterial growth resulting in greater volume of clogging material and exacerbating hydraulic performance problems (Houben and Treskatis 2007). The well pump can become fouled and inefficient through the same processes (Houben and Treskatis 2007; Smith and Comeskey 2010).

It should be noted that monitoring wells can also act as vertical conduits depending upon factors including length of well screen and location within the flow field. Such occurrences can be important for contaminated site cleanup and research has focused on understanding concentration data collected from monitoring wells (Reilly et al. 1989; Church and Granato 1996; Elci et al. 2001; Ma et al. 2011; McMillan et al. 2014; Vitale and Robbins 2016). However, the differences in construction between water supply wells and monitoring wells, primarily casing diameter and length of well screen, create the potential for greater flows through supply wells where there is less resistance to flow as well as greater head difference between shallow and deep strata. In general, the flow magnitudes and migration distances, both vertical and horizontal, are expected to be greater for water supply wells than monitoring wells. Vertical flow through monitoring wells is not considered in this work.

\section{Methods of investigation}

\section{Field work}

The general locations of wells investigated in the field are indicated on Fig. 1. Field examples Nos. 1 and 2 present intraborehole flow measurements, while field examples Nos. 3 and 4 address water-quality-impact evaluations. For field example No. 1, intraborehole flow under non-pumping conditions was measured on a project conducted by the author using a dye tracer method derived from the method of Izbicki et al. (1999). Similarly, field example No. 2 involved measuring intraborehole flow under non-pumping conditions on a project conducted by others (see discussion of field example below) using an impeller flowmeter (Welenco 1996; Keys 1997). The previously referenced measurement methods entail recording dye travel times and impeller rotation rates at different points along well screens to estimate intraborehole flows. For field example No. 3, water quality impact in the vicinity of a well that acted as a vertical conduit was evaluated on a project conducted by the author through (1) pumping the well for an extended period while monitoring nitrate concentrations in the discharge and (2) profiling flow into the well along the well screen with a dye tracer and obtaining depth-specific water samples for analysis using the previously referenced method of Izbicki et al. (1999). Finally, field example No. 4 entailed a hydrogeologic investigation on a project conducted by the author. Methods used included flow and concentration profiling along the well screen of a municipal well using the previously referenced method of Izbicki et al. (1999) as well as subsurface characterization by routine methods (monitoring well installation, water sampling and performing a pumping test).

\section{Management analysis}

\section{Well-specific approaches}

Options for managing intraborehole flow and transport on an individual well basis were explored through modeling a hypothetical two-aquifer system penetrated by a single well as in Fig. 3. The model was implemented as a half-space similar to Konikow and Hornberger (2006) using the MODFLOW-2000 (Harbaugh et al. 2000) and MT3DMS (Zheng and Wang $1999)$ modeling codes. Horizontal finite difference grid dimensions were $10 \times 10 \mathrm{ft}(3 \times 3 \mathrm{~m})$ in an area surrounding the simulated well (Fig. 5). Grid refinement to $0.25 \times 0.25 \mathrm{ft}$ $(8 \times 8 \mathrm{~cm})$ occurred for the well itself and grid coarsening was implemented towards the domain boundaries. Vertical grid dimensions were $10 \mathrm{ft}(3 \mathrm{~m})$ in the shallow aquifer and the intervening aquitard and $5 \mathrm{ft}(1.5 \mathrm{~m})$ in the deep aquifer. The shallow and deep aquifers were simulated as $100-\mathrm{ft}(30 \mathrm{~m})$ thick sands with horizontal hydraulic conductivity of $2.8 \times 10^{1} \mathrm{ft} /$ day $\left(10^{-2} \mathrm{~cm} / \mathrm{s}\right)$ and vertical hydraulic conductivity of $2.8 \mathrm{ft} /$ day $\left(10^{-3} \mathrm{~cm} / \mathrm{s}\right)$. The intervening aquitard was simulated as a $50-\mathrm{ft}(15 \mathrm{~m})$ thick clay with horizontal hydraulic conductivity of $2.8 \times 10^{-2} \mathrm{ft} /$ day $\left(10^{-5} \mathrm{~cm} / \mathrm{s}\right)$ and vertical hydraulic conductivity of $2.8 \times 10^{-3} \mathrm{ft} /$ day $\left(10^{-6} \mathrm{~cm} / \mathrm{s}\right)$. A spatially uniform storage coefficient value of $10^{-4}$ was used. Recharge was made horizontally uniform at a value of $3 \times 10^{-3} \mathrm{ft} /$ day $\left(9 \times 10^{-4} \mathrm{~m} /\right.$ day $)$. Specified-head boundary conditions that remained constant over time were set on the (1) up-flow and down-flow edges of the model grid in the aquifers to establish a horizontal hydraulic gradient of 0.001 and (2) bottom of the model grid to establish a downward vertical hydraulic gradient. The combination of the head boundary conditions and recharge resulted in a head difference across the aquitard of $7.5 \mathrm{ft}(2.3 \mathrm{~m})$ in the absence of the conduit well, which corresponded to a vertical gradient of -0.15 . The concentration of a conservative solute was set at $100 \mathrm{mg} / \mathrm{l}$ in the shallow aquifer and $10 \mathrm{mg} / \mathrm{l}$ in the deep aquifer. Advective solute transport was simulated using a porosity of 0.3 and implemented using the method of characteristics.

The 12-in $(30 \mathrm{~cm})$ diameter well casing and screen were simulated within a 24-in $(61 \mathrm{~cm})$ diameter borehole. An effective daily average pumping rate of $125 \mathrm{gal} / \mathrm{min}(473 \mathrm{l} / \mathrm{min})$, equivalent to $500 \mathrm{gal} / \mathrm{min}(1,893 \mathrm{l} / \mathrm{min})$ for $6 \mathrm{~h} /$ day, was applied; however, only half of this value was used since the 
Fig. 5 Groundwater model configuration. Arrows indicate model domain dimensions. The gray area indicates the location of the higher density finite difference grid. The red line indicates the conduit well location. Orange areas indicate specified head boundaries

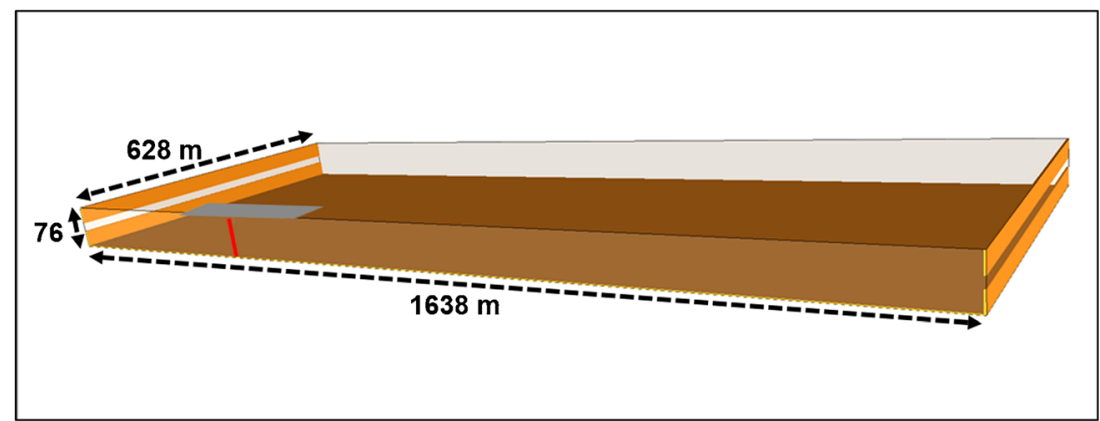

model was implemented as a half-space. The well consisted of (1) a $50 \mathrm{ft}(15 \mathrm{~m})$ long well seal from 0 to $50 \mathrm{ft}$ bgs $(0-15 \mathrm{~m}$ bgs), (2) a $50 \mathrm{ft}(15 \mathrm{~m})$ long well screen in the shallow aquifer placed immediately above the aquitard from 50 to $100 \mathrm{ft}$ bgs (15-30 m bgs), (3) a $50 \mathrm{ft}$ (15 m) long well screen in the deep aquifer placed immediately below the aquitard from 150 to $200 \mathrm{ft}$ bgs (45-60 m bgs) and (4) one continuous gravel pack from 50 to $205 \mathrm{ft}$ bgs (15-60 m bgs). The well was simulated with an assemblage of model grid cells (Horn and Harter 2009; Houben and Hauschild 2011). To simulate the well seal, inactive cells were placed at grid locations that corresponded to the borehole annulus and well casing from 0 to $50 \mathrm{ft}$ bgs $(0-$ $15 \mathrm{~m}$ bgs). The gravel pack was simulated with horizontal and vertical hydraulic conductivities set at $2.8 \times 10^{3} \mathrm{ft} /$ day, or $1 \mathrm{~cm} / \mathrm{s}$, generally consistent with Houben and Hauschild (2011). To simulate flow in the well, a value one hundred times that of the gravel pack $\left(2.8 \times 10^{5} \mathrm{ft} /\right.$ day, or $\left.100 \mathrm{~cm} / \mathrm{s}\right)$ was used for cells at grid locations that corresponded to the inside of the well. This value was, however, lower than that predicted for laminar flow conditions by Hagen-Poiseuille $\left(2.5 \times 10^{6} \mathrm{~cm} / \mathrm{s}\right)$ in order to simulate enhanced head loss within the well during pumping as a result of turbulence. This approach was reasonable given that the Reynolds number for the specified casing diameter and pumping rate would be well beyond the upper range for laminar flow $\left(1.2 \times 10^{5}\right.$ compared to $2.1 \times 10^{3}$; Vennard and Street 1982).

Simulating the unmanaged case entailed modeling transient flow and transport with a pumping schedule as follows: inactivity from day 0 through 180 , pumping from day 181 through 360, inactivity from day 361 through 540, pumping from day 541 through 720 . Consistent with typical pump settings for water supply wells, the pump intake location was simulated as located in the well casing above the shallower screen. Management options were evaluated by changing the pumping schedule and pump intake depth.

Representing the well as an equivalent porous medium, rather than using the MODFLOW Multi-Node Well Package (Konikow et al. 2009), was consistent with previous approaches by some researchers (Lacombe et al. 1995; Halford 2009; Horn and Harter 2009; Halford et al. 2010; Houben and Hauschild 2011; Mejia et al. 2012; McMillan et al. 2014) and allowed simulation of head loss as water flowed vertically inside the well during pumping. Because the MODFLOW Multi-Node Well Package assumes no head loss inside the well, it may overallocate pumping flows along the well screen for portions of the screen located farthest from the pump. In such cases, variation in the areal extent of the groundwater capture zone with depth and the potential migration of solutes beyond the capture zone would not be properly simulated. One of the management approaches addressed in this work, changing the pump depth to adjust the capture zone extent with depth, required the simulation of head loss inside the well; therefore, the Multi-Node Well Package was not used. Since this work also simulates intraborehole flows under non-pumping conditions, the selected approach may underestimate those flows because of the lower hydraulic conductivity used inside the casing. As a result, expected volumes transferred between aquifers could be larger and water quality impacts could be greater than those simulated.

\section{Regional approaches}

Options for managing intraborehole flow and transport by focusing limited resources on a regional basis were explored using geographical analysis of well construction log data. The northern portion of California's Central Valley (Fig. 1) was used for demonstration based on data availability but the concepts apply more broadly. The number and diameter of wells in the study area were tabulated on a $1-\mathrm{mi}(1.6-\mathrm{km})$ grid spacing, then the increase in vertical hydraulic conductivity was estimated using the method presented in the Appendix. When combined with a threshold for factor increase in natural vertical hydraulic conductivity, the results can be used to target areas of potential high impact for investigation.

\section{Results and discussion of field investigations}

\section{Measurements of intraborehole flow}

Field example No. 1: upward flow in a regional discharge area

A 14-in $(36 \mathrm{~cm})$ diameter well near the Sacramento River (see No. 1 on Fig. 1) was investigated to determine the cause of 
water quality impact. Part of the investigation involved measuring intraborehole flow. Figure 6a presents a cumulative flow profile under ambient conditions during the winter. (Cumulative flows are measured inside the well along its length.) Upward flow occurred over the entire 229-ft (70 m) screened interval. Upward hydraulic gradients and groundwater flow are common in areas where the saturated zone is in contact with the river and seasonal pumping stresses do not prevent natural groundwater discharge. The maximum flow along the well was approximately $35 \mathrm{gal} / \mathrm{min}(132 \mathrm{l} / \mathrm{min})$.

Figure $6 \mathrm{~b}$ presents the incremental flow profile for the data presented in Fig. 6a as well as the depths and thicknesses of sand layers identified in the lithologic log that was recorded when the wellbore was drilled. (Incremental flows are flows into and out of the well calculated as differences between vertically adjacent flow measurements inside the well with upstream subtracted from downstream.) Depths of the larger inflows and outflows generally coincided with the sand layers. Depths where flows occurred without indications of sand could result from inaccuracies in the lithologic log (sand actually present) or interaction of flows inside the well with the gravel pack. Even though the entire screened interval for this well was within the same water-bearing zone, stratification of the alluvial sediments created conditions conducive to the long-screened well acting as vertical conduit for flow (development of vertical hydraulic gradients and a preferential flow path through the well as a result of the contrast in hydraulic
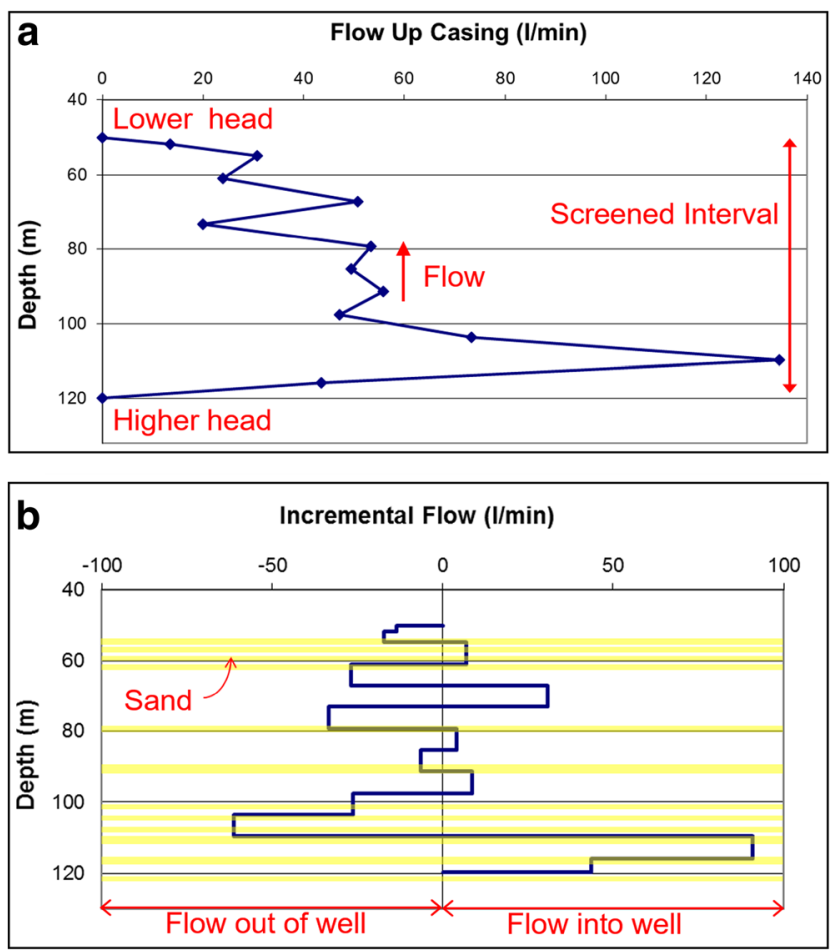

Fig. 6 Field example No. 1: a cumulative flow profile conducted under ambient (nonpumping) conditions; $\mathbf{b}$ incremental flow profile derived from the cumulative flow profile conductivity between the fine-grained strata contained in the alluvial sequence and the open well structure).

\section{Field example No. 2: downward flow in a heavily pumped basin}

Figure 7a presents a schematic for an experimental well installed in southern California by the Orange County Water District (OCWD) to evaluate the possibility of conveying recharge water to depth through wells (see No. 2 on Fig. 1). A significant amount of water enters the groundwater system as recharge to the shallow aquifer through artificial ponds and exits the system through water supply wells pumping from the deeper Principal Aquifer. However, an aquitard present from approximately $185-230 \mathrm{ft}$ bgs $(56-70 \mathrm{~m} \mathrm{bgs})$ impedes the flow of water between aquifers. The well was constructed of 8 -in $(20 \mathrm{~cm})$ diameter casing and wire-wrapped screen. There was one $25-\mathrm{ft}(8 \mathrm{~m})$ screened interval in the shallow aquifer and three screened intervals with a combined length of $49 \mathrm{ft}$ $(15 \mathrm{~m})$ in the Principal Aquifer.

Figure $7 \mathrm{~b}$ presents results of 24 flow measurements collected by OCWD with an impeller flowmeter between the shallowest and deeper screened intervals over 47 months. Flows ranged between approximately 80 and $360 \mathrm{gal} / \mathrm{min}$ (300 and 1,360 l/min). Based upon measurements from shallow and deep short-screened monitoring wells located approximately $38 \mathrm{ft}(12 \mathrm{~m})$ away from the experimental well, the head difference across the aquitard varied between approximately 14 and $38 \mathrm{ft}$ (4 and $12 \mathrm{~m}$; Fig. 7b). Using these head differences and the aquitard thickness, the vertical hydraulic gradient driving flow down the well was calculated as ranging from approximately -0.3 to -0.8 . The flow measurements indicate that approximately $350 \times 10^{6} \mathrm{gal}\left(1.3 \times 10^{9} \mathrm{l}\right)$ of water flowed down the well over the 47 -month monitoring period.

Figure $7 \mathrm{c}$ plots the decrease over time in rate of flow divided by the observed head difference across the aquitard. This trend is taken as an indication that the deeper well screens, gravel pack and, possibly, the sediments in the nearwell environment began to clog. The causes of clogging were not investigated by OCWD but could have included several processes discussed in the previous (accumulation of suspended sediments as well as development of inorganic precipitation and/or bacterial growth resulting from mixing of geochemically different waters).

\section{Extent of water quality impact}

Field example No. 3: water quality degradation at the well scale

A 16-in $(41 \mathrm{~cm})$ diameter well in the Sacramento Valley was investigated to determine the cause of nitrate contamination (see No. 3 on Fig. 1). The lithologic log for the well and other 
Fig. 7 Field example No. 2: a schematic of experimental transfer well (Blue symbols indicate piezometric levels at different depths in the groundwater system), b flows in well under ambient conditions and head differences driving flows, and $\mathbf{c}$ change in flow response to driving head difference over time
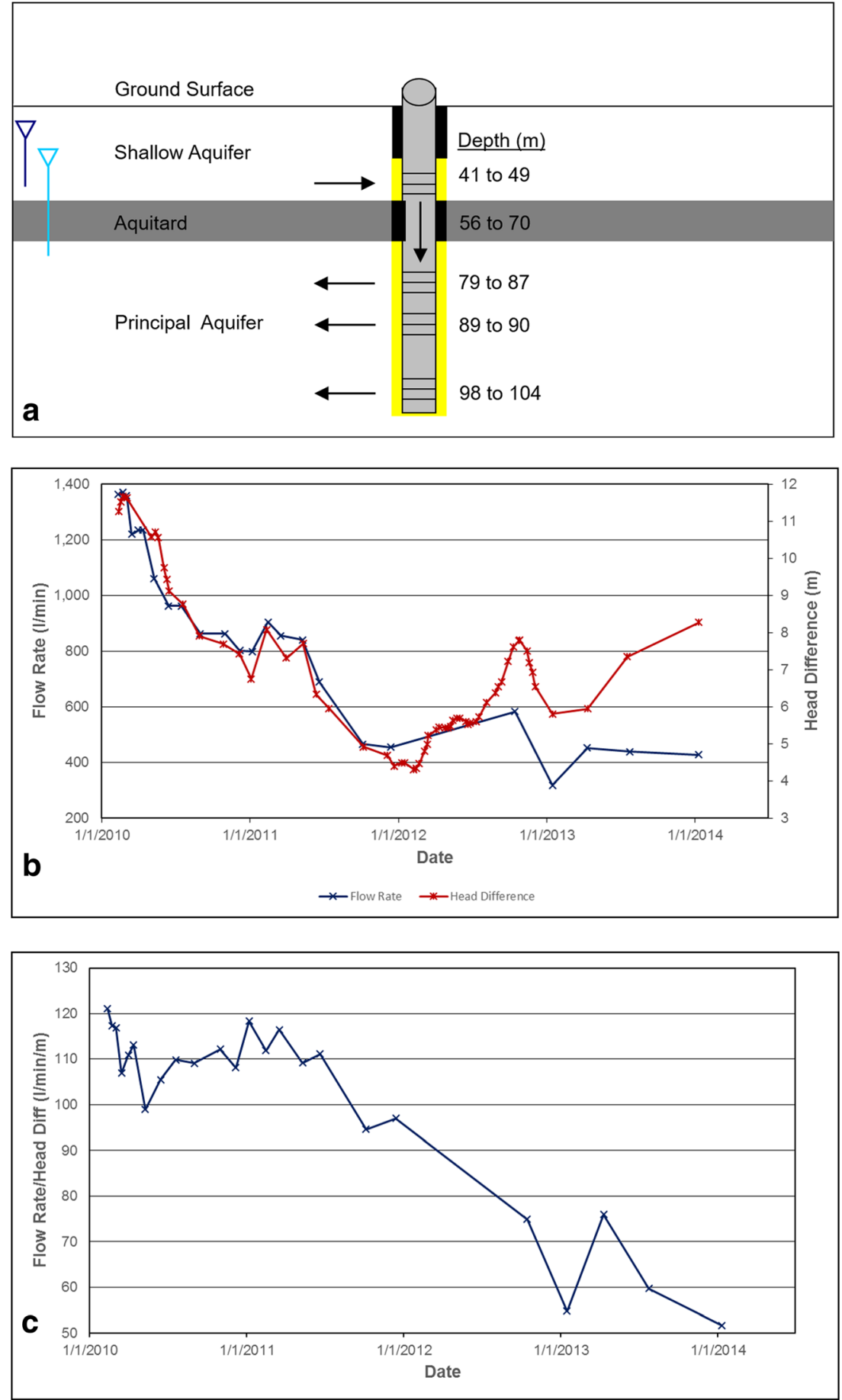

available information regarding the local geology indicated that the sediments in the groundwater basin comprised a stratified sequence of finer and coarser materials. Significant groundwater pumping and agricultural irrigation occurred in the area and downward hydraulic gradients had been measured in the greater vicinity of the well. The seven screened intervals for the well spanned a significant vertical distance (451 ft, or $137 \mathrm{~m}$; Fig. 8a) and the well had not been pumped for over 1 year. Together, these conditions created the potential for the well to act as a vertical conduit for downward flow and migration of shallow contaminants to depths where better quality water was present.

Figure 8 a presents incremental nitrate water-quality profiles for the well collected under pumping conditions at different times as the well was continuously purged for an extended period. The later-time profiles indicate that nitrate concentrations decreased with depth. This is consistent with (1) the constituent source being at the ground surface, (2) concentration 

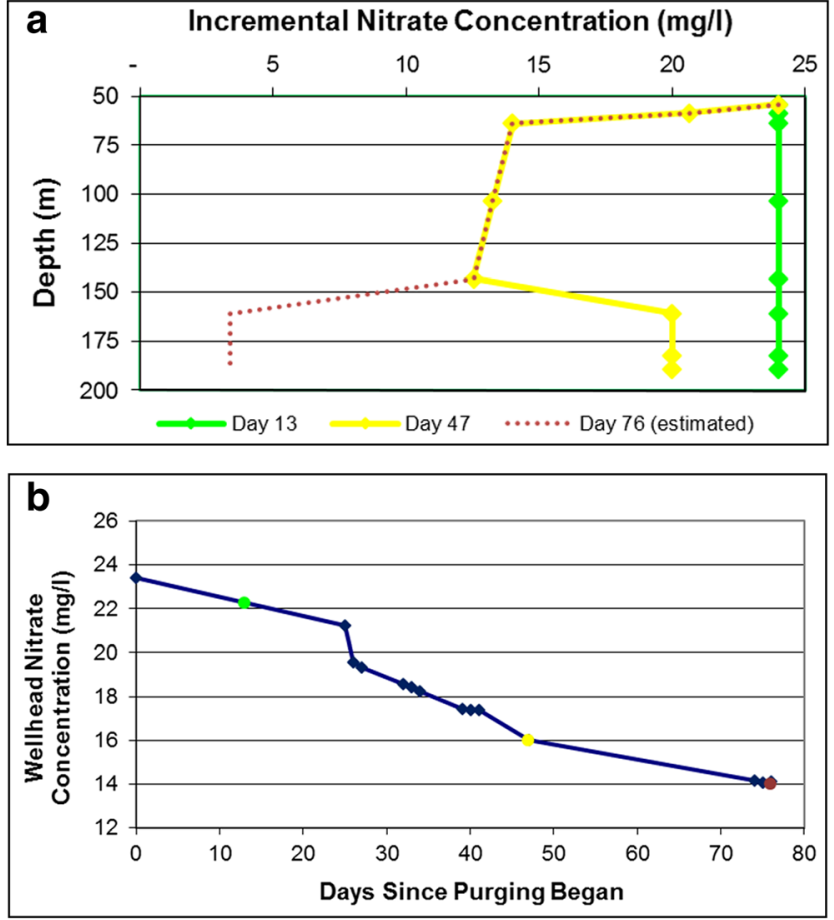

Fig. 8 Field example No. 3: a Evolution of an incremental nitrate concentration profile with extended purging (A cumulative water quality profile consists of concentrations associated with samples collected from inside the well, while an incremental water quality profile is the result of differencing the flow-weighted cumulative concentration profile as described by Izbicki et al. 1999. The incremental water-quality profile indicates the depths and concentrations of dissolved constituents in the strata adjacent to the well screen. Day 76 concentration profile at depths greater than $150 \mathrm{~m}$ estimated based upon day 76 wellhead concentration, shallower portion of Day 47 concentration profile and the incremental flow profile.); b Nitrate concentration decrease at wellhead during extended period of well pumping. Colored diamonds (a) indicate the incremental concentrations. Colored circles (b) correspond to profiles presented (a). The applicable drinking-water quality standard is $45 \mathrm{mg} / 1$

attenuation with distance from a solute source and (3) increased application rates over time along with long transport times to the deeper part of the groundwater system. Figure $8 \mathrm{~b}$ presents the wellhead concentrations over a 76-day period when the well was pumped continuously at $600 \mathrm{gal} / \mathrm{min}(2,270 \mathrm{l} / \mathrm{min})$. The initial concentration from the pumping period (slightly less than $24 \mathrm{mg} / \mathrm{l}$ on Fig. 8b) was consistent with a mix of concentrations from the two shallowest depths sampled for the profile (21 and $24 \mathrm{mg} / \mathrm{l}$ on Fig. 8a). These observations are consistent with the expectation that the well acts as a vertical conduit for downward flow and contaminant migration during periods of no pumping. Referring back to Fig. 4a, groundwater that contained nitrate concentrations from the shallower strata migrated down through the well, displaced water at depth that contained lower concentrations, and created a zone near the well containing relatively uniform water quality along the entire well screen. Consistent with Fig. $4 \mathrm{~b}$, water quality at the beginning of pumping reflected shallow water quality since the water located along the entire length of the well screen originated in the shallower strata. As pumping progressed, the higher concentration water that had migrated to depth was removed from the deeper strata and the well ultimately pumped from the heterogeneous distribution of water quality representative of conditions in the greater vicinity of the well (day 76 on Fig. 8a).

Dynamic (pumping) flow and water quality profiles for the well at 13 and 47 days into the 76-day pumping period document the well purging process. The incremental water quality profiles for these data collection events are presented on Fig. 8a. After 13 days of pumping, the water quality profile was homogeneous with a single concentration along the well screen that was consistent with shallow water quality. At this point, with a pumping rate of $600 \mathrm{gal} / \mathrm{min}(2,270 \mathrm{l} / \mathrm{min})$, over $11 \times 10^{6}$ gal $\left(42 \times 10^{6} 1\right)$ of water containing a relatively high nitrate concentration had been extracted. Clearly, a larger volume of water had migrated down the well. After 47 days of pumping, concentrations decreased with depth, as would be expected once the well was purged, for all but the deepest portion of the water quality profile. The effects of shallow water migrating to depth through the well had been reversed in the sandier strata. Only the deeper strata containing clay, as indicated by the lithologic log, retained poorer quality water that had migrated from the shallower strata. After another 29 days, the effects of contaminated water flowing down the well while it was inactive appeared to have been fully reversed. These data clearly illustrate two points: (1) purging a well after long periods of inactivity can require weeks to months and (2) adequate purging of water supply wells before concentration profiling is necessary to obtain accurate information.

A total of more than $65 \times 10^{6} \mathrm{gal}\left(246 \times 10^{6} 1\right)$ of water was pumped to reverse the effects of the well acting as a vertical conduit. In this case, the vertical flow did not create a water quality problem because the nitrate concentration in the migrating water (21-24 mg/l) was below the drinking water standard $(45 \mathrm{mg} / \mathrm{l})$ and no action was required. However, shallower groundwater concentrations of nitrate, and possibly other constituents, exceed drinking water standards in many areas. The final example considers such a case.

\section{Field example No. 4: water quality degradation at the wellfield scale}

The wells considered in this example were near the Sacramento-San Joaquin River Delta (see No. 4 on Fig. 1). Groundwater pumping and agricultural irrigation are prevalent in the area. Lithologic logs for nearby wells plus other information on the local geology indicated a stratified sequence of finer and coarser sediments within the groundwater system. Consistent with these conditions, a downward vertical hydraulic gradient had been documented locally. A pressure transducer survey was conducted for 13 months using monitoring wells with 20 -ft $(6 \mathrm{~m})$ screens. Two shallow and two 
deep wells were installed to approximately 35 (shallow) and 180 (deep) ft bgs (11 and $55 \mathrm{~m}$ bgs) and equipped with pressure transducers. The data collected showed downward vertical hydraulic gradients throughout the year with seasonal variation that coincided with pumping. Gradients were between 0 and -0.01 during the winter and roughly doubled to between -0.01 and -0.02 during the irrigation season. A 30-day pumping test on a nearby municipal well screened in the deeper portion of the groundwater system at approximately $2,000 \mathrm{gal} / \mathrm{min}(7,570 \mathrm{l} / \mathrm{min})$ increased the gradients to between -0.03 and -0.04 at a distance of approximately $1,000 \mathrm{ft}(305 \mathrm{~m})$ from the pumping well. Horizontal hydraulic gradients varied somewhat from shallow to deep and between seasons but were less than or equal to 0.001 .

An 8-5/8-in $(22 \mathrm{~cm})$ diameter industrial supply well constructed in 1974 to a depth of approximately $200 \mathrm{ft}$ bgs $(61 \mathrm{~m}$ bgs) had an annular seal that extended to the minimum regulatory standard of $50 \mathrm{ft}$ bgs $(15 \mathrm{~m} \mathrm{bgs})$ and a gravel pack that extended from approximately 150 to $200 \mathrm{ft}$ bgs $(46-61 \mathrm{~m}$ bgs). It was not clear what type of material was used to fill the annular space from 50 to $150 \mathrm{ft}$ bgs $(15-46 \mathrm{~m} \mathrm{bgs})$. Possibilities included gravel pack as well as a collapse of the borehole and infilling with the surrounding mix of sediments. A $20-\mathrm{ft}(6 \mathrm{~m})$ screen was present at the bottom of the well. This well was on the grounds of a fertilizer formulation facility where shallow groundwater was highly contaminated with nitrate. Proximity of the industrial supply well to shallow groundwater contamination and the short annular seal created potential for nitrate migration to depths with better water quality. Decades after the industrial supply well was constructed, the afore-referenced municipal supply well capable of producing approximately $2,000 \mathrm{gal} / \mathrm{min}(7,570 \mathrm{l} / \mathrm{min})$ was installed approximately $1,100 \mathrm{ft}(335 \mathrm{~m})$ from the industrial supply well. The proximity of the high-capacity municipal well increased downward vertical gradients in the area during pumping operations.

The higher nitrate concentrations in shallow groundwater near the industrial supply well ranged from approximately 1,000 to $4,000 \mathrm{mg} / \mathrm{l}$ nitrate (compared to a drinking water standard of $45 \mathrm{mg} / \mathrm{l})$. The industrial well was pumped only intermittently and seasonal variations in nitrate concentration at the wellhead ranged from approximately 20 to $900 \mathrm{mg} / 1$. Ten years of water quality data indicated that the highest concentrations occurred in the well during summer when downward gradients were the greatest. Investigation of the groundwater nitrate distribution, as well as groundwater age dating (Singleton et al. 2010), indicated impacts to deeper water quality (Fig. 9). The concentration at the industrial well $(917 \mathrm{mg} / \mathrm{l}$ on Fig. 9) was higher than in surrounding wells screened at similar depths by a factor of ten or more. Also, the vertical distribution of nitrate in the municipal supply well did not decrease with depth, as was the case for example No. 3 above, which would be expected for a constituent where the source is at ground surface. Furthermore, the groundwater age distribution indicated younger water at depth near the industrial supply well (average of 27 years on Fig. 9) relative to the surrounding groundwater by a factor of as much as $100 \%$. These observations indicated that the industrial supply well acted as a vertical conduit for downward flow and nitrate migration and that the impact to groundwater quality extended more than $1,000 \mathrm{ft}(300 \mathrm{~m})$ from the well.
Fig. 9 Field example No. 3: Nitrate concentrations and groundwater age in the vicinity of an industrial supply well acting as a vertical conduit. Data from Singleton et al. (2010) and this study

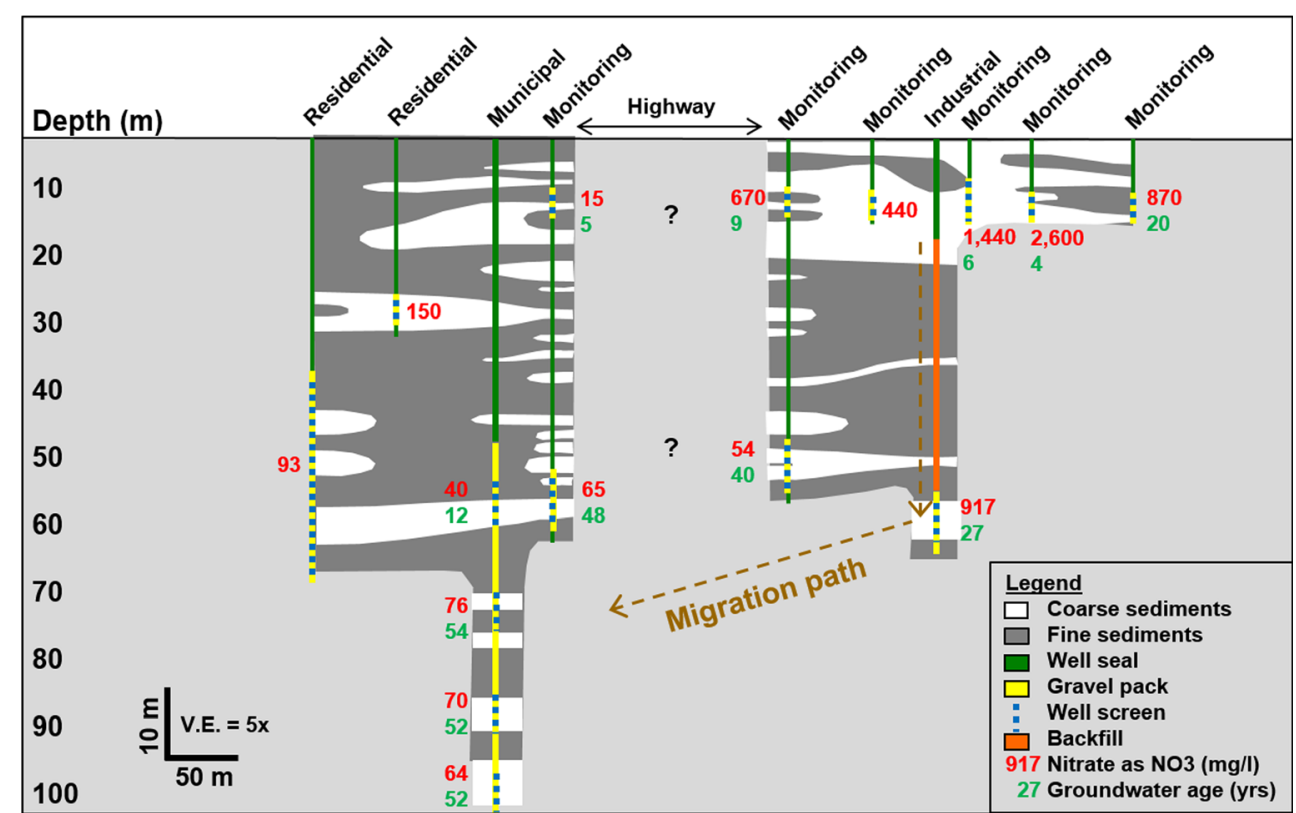




\section{Results and discussion of management analysis}

\section{Well-specific approaches}

The volume of water transferred between strata through a well that acts as a conduit depends upon magnitude and duration of flow. A sustained flow of only $1 \mathrm{gal} / \mathrm{min}(4 \mathrm{l} / \mathrm{min})$ becomes 1,440 gal $(5,4501)$ in a day and over $260 \times 10^{3}$ gal $\left(992 \times 10^{3} 1\right)$ in a 6-month period of inactivity (a representative duration of inactivity for wells used seasonally). Figure 10a-d depicts simulated results of flow and contaminant migration down a typical well that is pumped only seasonally in a layered sand and clay system.

Over the 24-month simulation period, inactive and pumping periods of 6 months each occur in a series. Approximately $4.3 \times 10^{6}$ gal $\left(16 \times 10^{6} 1\right)$ of groundwater is redistributed from the shallow to deep aquifer during each inactive period and approximately $33 \times 10^{6} \mathrm{gal}\left(124 \times 10^{6} 1\right)$ is pumped from the groundwater system during each active period. Only $29 \%$ of the volume extracted comes from the deep aquifer because the well pump is positioned above the shallower screen, head loss occurs in the well casing and there is a downward hydraulic gradient. Moreover, the vast majority of flow to the well in the deep aquifer is delivered from the up flow direction by regional flow. Only $6 \%$ of the volume extracted comes from the down flow direction in the deep
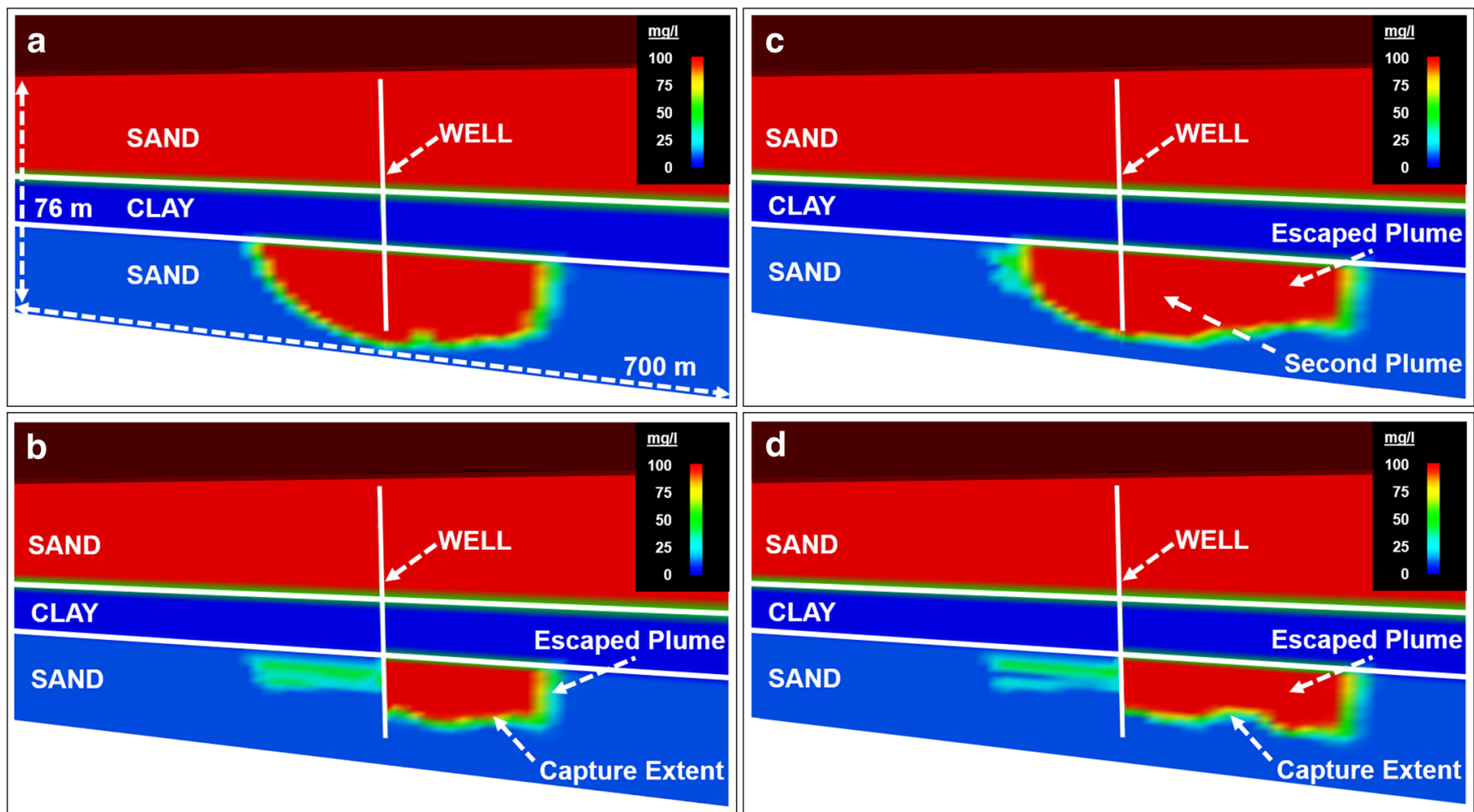

Fig. 10 Simulated flow and transport in a conduit well: a contaminant migration to the deeper zone while the well is idle for 180 days (days 1180 ); b pumping the well for 180 days (days 181-360); c a second 180- aquifer, which limits the down flow capture zone extent and the regional flow system transports some of the water transferred during inactive periods away from the well. This uncaptured water transfers contaminant mass to the deep aquifer where it mixes with better quality water and degrades the resource.

To prevent such contamination, local regulatory requirements and industry standards for well construction should be followed when constructing new wells (i.e., CADWR 1991, 2003). Because regulatory criteria often provide only minimum requirements and are prepared in the absence of sitespecific details, more stringent design criteria such as shorter screened intervals and gravel packs, may be warranted in some cases. The hydrogeology for each new well site should be considered during design development. Key information to consider includes sediment stratigraphy and depositional environment, variations in vertical hydraulic gradient over the year, water quality near the well site and potential changes in conditions over the life of the well (well condition, aquifer stresses and water quality). In addition, best methods should be applied when abandoning test holes since a test hole also can act as a vertical conduit. This includes isolating vertically separate water-bearing strata using sealing materials that will remain stable.

Where significant water quality impacts occur from existing wells acting as vertical conduits, operational and/or

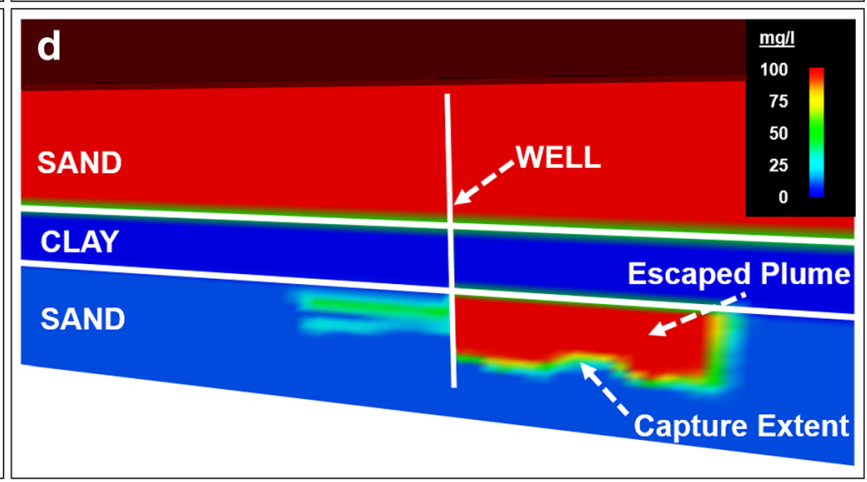

day period when the well is idle (days 361-540); d a second 180-day period of pumping the well (days 541-720) 
structural changes should be considered. Operational changes could include implementing intermittent pumping during periods of low demand to control migration through a well. Comparison of Fig. 11a,b with Fig. 10b,d demonstrates the improvement in water quality from more frequent pumping, by a factor of two in this case, to limit contaminated water migration out of the well capture zone. This approach would only be possible when at least some water demand exists during the off-season and rotation of pumping among wells is possible. Structural changes could include changing the depth of the pump intake (moving the pump deeper in the case of water flowing downward through a well). Comparison of Fig. 11c,d with Fig. 10b,d conceptually demonstrates the improvement in water quality from moving the pump deeper in the well to reduce the amount of contaminant mass that escapes the well when pumping. Approximately $48 \%$ of the extracted volume comes from the deep aquifer, as opposed to $29 \%$ when the pump was higher in the well, and much less of the plume escapes. Other structural changes could include installing patches or packers to prevent contaminated water from entering and migrating through the well and injecting cement into the gravel pack within some intervals to prevent migration along the outside of the well. Finally, destroying wells should include application of methods that target the migration pathways of concern and collection of sufficient confirmatory information so that wells do not act as conduits for vertical contaminant migration after their useful lives have ended - for example, where a long gravel pack exists above the screen outside the well casing, it may be appropriate to perforate the casing to allow injection of sealing material.

\section{Regional approaches}

Considering the great number of wells that exist in many groundwater basins and the length of time they remain open in the subsurface (from decades to perpetuity unless the well is properly destroyed), contaminant migration similar to that described here is likely to occur at many locations and on a variety of spatial scales (well, wellfield and region). In many cases, the risks are not fully understood because important information regarding well operations and local hydrogeology is absent. The challenge of protecting groundwater quality under such circumstances is great and efforts to focus limited resources for investigation and corrective measures are needed. An available data set for a portion of northern California provides the opportunity to outline a possible approach.

Figure 12a summarizes a dataset recently constructed by the CADWR for geographic occurrence of water supply wells in the northern portion of California's Central Valley. There are 75,974 total wells of which 56,781 are domestic; 16,354
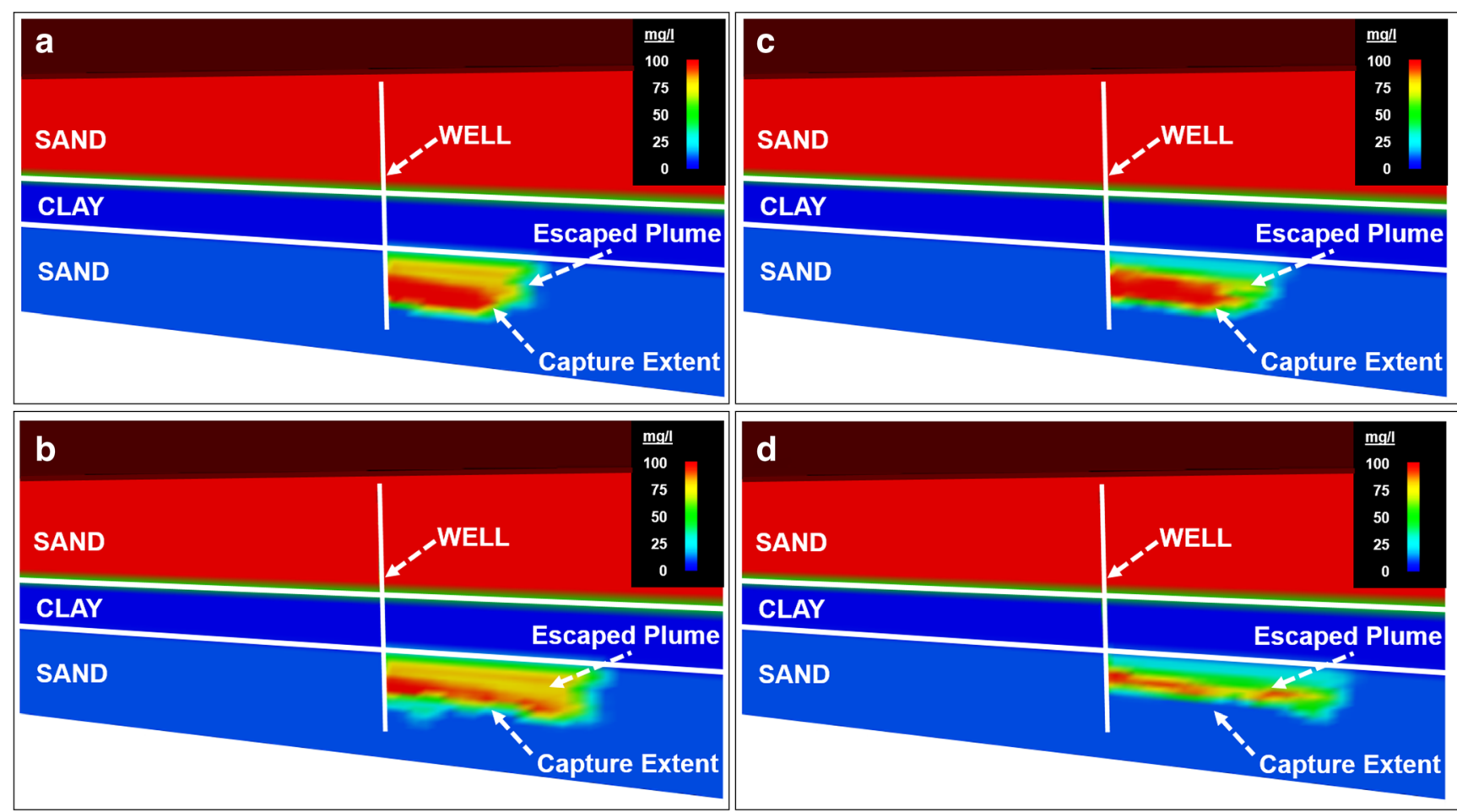

Fig. 11 Simulated flow and transport in a modified well: a resting and pumping the well every 90 days over a period of 360 days; $\mathbf{b}$ resting and pumping the well every 90 days over a period of 720 days; $\mathbf{c}$ moving pump deeper in well so that it is adjacent to the deeper water-bearing unit then resting and pumping the well every 180 days over a period of

360 days; $\mathbf{d}$ moving pump deeper in well and pumping the well every 180 days over a period of 720 days. The results for 360 and 720 days should be compared with parts b and d, respectively, of Fig. 10. All other details of the simulations are as described in section 'Well-specific approaches' 


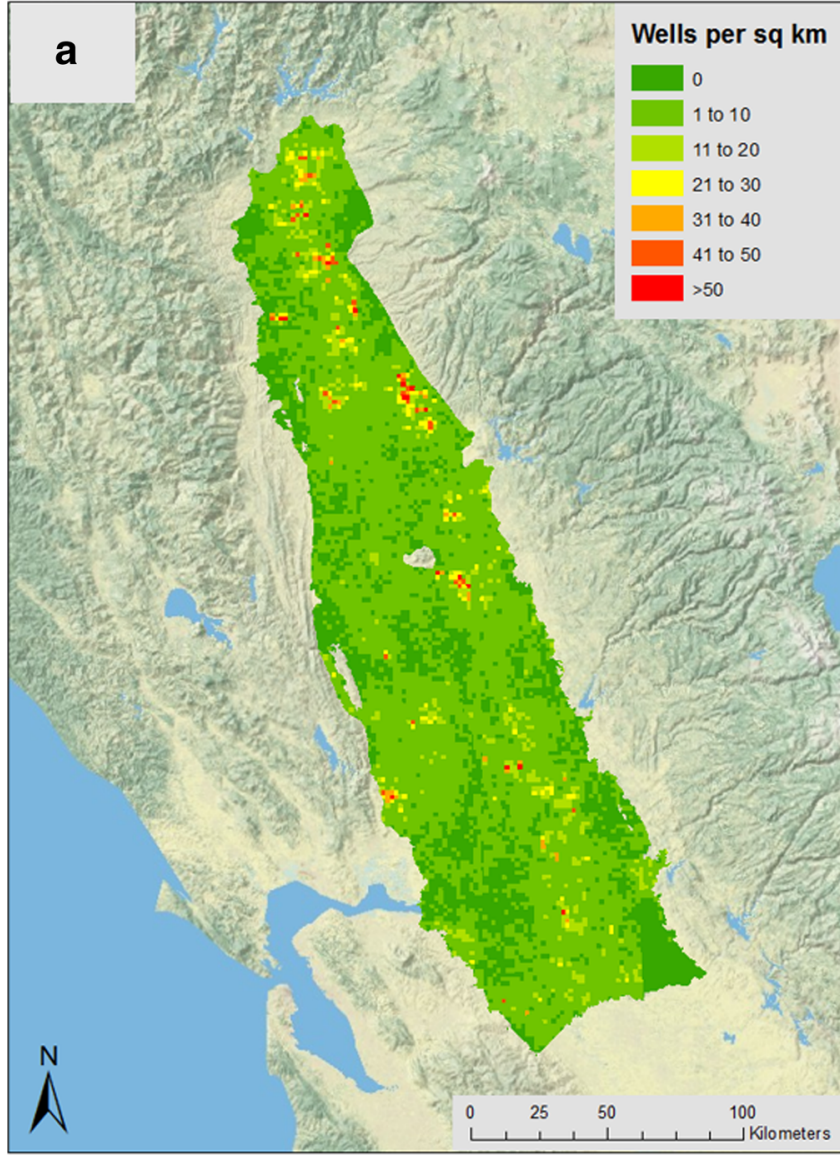

Fig. 12 Example screening approach for assessing potential impact of wells that act as conduits: a water well density in the northern Central Valley of California and $\mathbf{b}$ worst-case assessment of increase in vertical

are for irrigation; 1,913 are for public supply and 926 are for industrial use. These wells vary in age from 1 year $(2 \%)$ to more than 60 years $(13 \%)$, with a median age of 36 years, and likely exist in a wide range of maintenance conditions. Depths of completion vary from $40 \mathrm{ft}(12 \mathrm{~m}, 1 \%)$ to over $500 \mathrm{ft}$

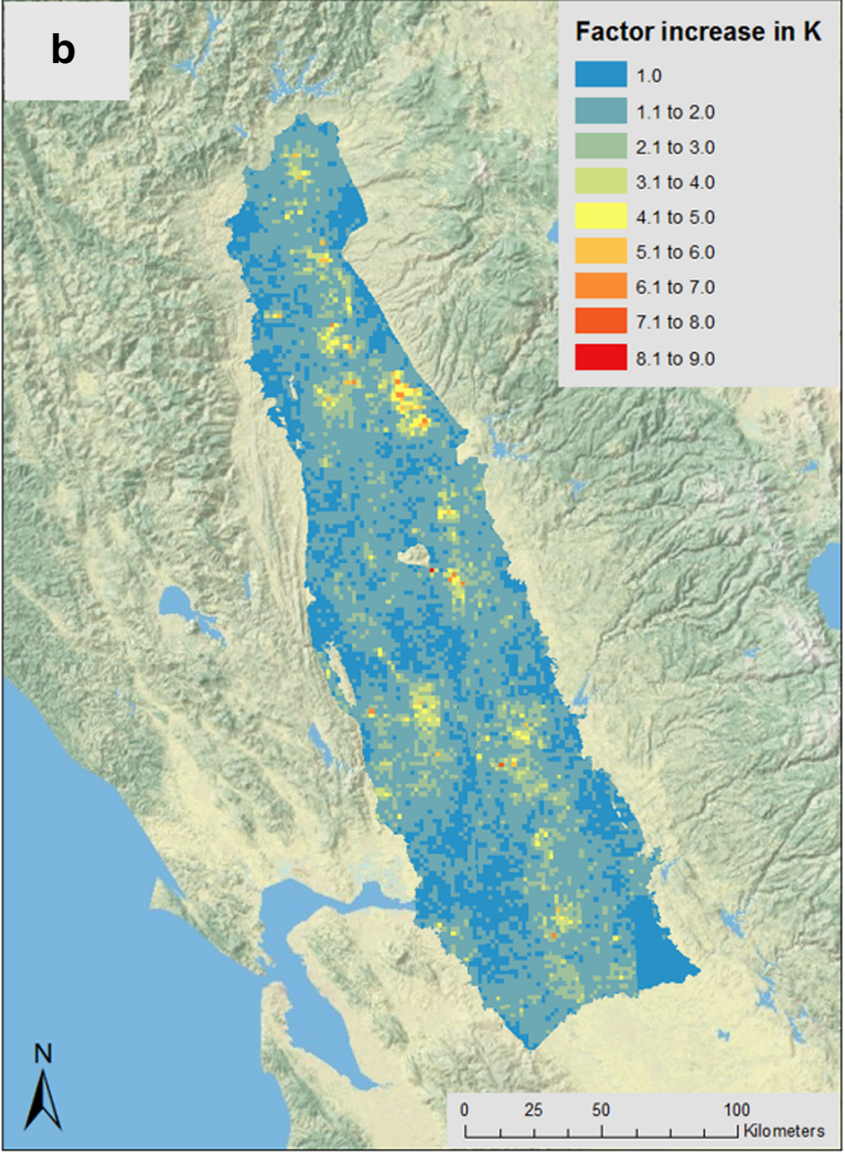

hydraulic conductivity of groundwater system resulting from water wells acting as vertical conduits for flow. A factor increase of 2 indicates a doubling of the vertical hydraulic conductivity

$(152 \mathrm{~m}, 5 \%)$ with a median of $180 \mathrm{ft}(55 \mathrm{~m})$. The combination of hydrogeologic and well conditions (stratified alluvial sediments, pumping at depth, irrigation water applied at ground surface, poorer shallow groundwater quality in places and long well constructions) creates the potential for these wells

Table 3 Summary of case examples for wells acting as vertical conduits

\begin{tabular}{|c|c|c|c|c|}
\hline Field example & No. 1 & No. 2 & No. 3 & No. 4 \\
\hline Hydrostratigraphy & $\begin{array}{l}\text { Alternating fine- and } \\
\text { coarse-grained strata }\end{array}$ & Sand/aquitard & $\begin{array}{l}\text { Alternating fine- and } \\
\text { coarse-grained strata }\end{array}$ & $\begin{array}{l}\text { Alternating fine- and } \\
\text { coarse-grained strata }\end{array}$ \\
\hline Hydrologic stress & Regional discharge to river & Deep pumping recharge operations & Deep pumping irrigation & Deep pumping irrigation \\
\hline Vertical gradient $\mathrm{a}^{\mathrm{a}}$ & Upward & -0.3 to -0.8 & Downward & 0 to -0.04 \\
\hline Screen length (m) & 70 continuous & Upper: 8; lower: 15 & 18 total across 137 & 6 continuous \\
\hline Gravel pack length (m) & 106 & Upper: 11; lower: 29 & None & Confirmed: 15 ; likely: 46 \\
\hline Casing diameter $(\mathrm{cm})$ & 36 & 20 & 41 & 22 \\
\hline Flow rate $(1 / \mathrm{min})$ & 132 & $300-1,360$ & Unknown & Unknown \\
\hline Volume transferred (L) & Unknown & $1.3 \times 10^{9}$ & $>246 \times 10^{6}$ Impacted & Unknown but regional \\
\hline Timeframe & May reverse seasonally & 47 months & Unknown & Seasonal over decades \\
\hline Contaminant present? & Yes & No & Yes & Yes \\
\hline
\end{tabular}

${ }^{a}$ Negative vertical gradient indicates downward flow 
to act as conduits for vertical migration of contaminants as described in the preceding. Figure $12 \mathrm{~b}$ summarizes a worstcase calculation of the potential increase in effective vertical hydraulic conductivity for the groundwater system from water supply wells penetrating lower hydraulic conductivity strata. Details of the calculation are presented in the Appendix.

In areas of higher well density, the vertical hydraulic conductivity could increase by a factor of five to ten. Results similar to those presented on Fig. $12 \mathrm{~b}$ could be combined with information on shallow water quality so areas that pose a higher risk to groundwater quality (high density of wells and poor shallow water quality) could be prioritized for investigation. In the high-priority areas, the effects of vertical flow through wells might be evaluated through routine waterquality monitoring upon renewed pumping after periods of inactivity. Further evaluation such as video logging and ambient flow measurement, could be performed as circumstances warrant. Responses to discovered problems, possibly repairs to casings or changes in pumping operations as discussed previously, could be implemented accordingly.

\section{Conclusions}

Table 3 summarizes the field examples previously presented. While most cases discussed here are in or near agricultural settings, the observations presented on the potential for wells to act as vertical conduits and degrade groundwater quality are also pertinent to urban or urbanizing (converting from agricultural to urban use) areas. Whenever the combination of hydrologic stresses and stratigraphy in a groundwater basin creates vertical hydraulic gradients and there is also vertical heterogeneity in concentrations of undesirable water quality constituents, the potential exists for contaminant migration through idle wells that are improperly constructed or maintained.

Wells that act as conduits may create water quality impacts for themselves as well as for the surrounding water-bearing zones and nearby wells. Therefore, special consideration should be given to the construction, maintenance and management of water supply wells when the conditions for intraborehole flow exist or are reasonably expected to exist. The information necessary for designing wells against vertical flow and water quality impacts has been available since at least the early 1960s (Johnson 1961; CADWR 1962); nevertheless, examples of the phenomenon appear to be fairly common. Continued and additional efforts are needed to protect groundwater quality from improperly constructed and maintained wells.

Acknowledgements The author is grateful to the Orange County Water District for sharing data and results presented in field example No. 2 and to the California Department of Water Resources (Data Collection and Management Section, Northern Region Office) for sharing data regarding the geographic distribution of water supply well constructions in the northern Central Valley of California upon which the results in Fig. 12a, b are based.
Graham Fogg, Thomas Harter and Jay Lund are also appreciatively acknowledged for discussions and editorial comments that significantly improved this manuscript. Christoph Weidner also provided valuable comments on the final manuscript. This work was supported by UC Water Security and Sustainability Research Initiative funded by the University of California Office of the President (UCOP; Grant No. 13941) and by the S.D. Bechtel Jr. Foundation through the UC Davis Center for Watershed Sciences.

\section{Appendix}

A screening approach was used to estimate the potential increase in effective vertical hydraulic conductivity discussed in section 'Regional approaches'. It is based upon summation of vertical flows in the region of consideration:

$Q_{\text {regional }}=Q_{\text {strata }}+\sum_{j=1}^{n}\left(Q_{\text {well }}\right)_{j}$

where:

$Q_{\text {regional }}$ is the total vertical flow through the groundwater system in the region

$Q_{\text {strata }} \quad$ is the vertical flow through strata in the region

$Q_{\text {well }} \quad$ is the vertical flow through a well acting as a conduit

$n \quad$ is the number of wells acting as conduits in the region

Substitution of Darcy's Law into Eq. (1) yields:

$$
\begin{aligned}
& K_{\text {effective }} i_{\text {regional }} A_{\text {regional }} \\
& =K_{\text {strata }} i_{\text {regional }}\left(A_{\text {regional }}-\sum_{j=1}^{n}\left(A_{\text {well }}\right)_{j}\right) \\
& \quad+\sum_{j=1}^{n}\left(A_{\text {well }} i_{\text {well }} A_{\text {well }}\right)_{j}
\end{aligned}
$$

where:

$K_{\text {effective }}$ is the effective vertical hydraulic conductivity for the groundwater system in the region

$i_{\text {regional }}$ is the average vertical hydraulic gradient for the region

$A_{\text {regional }} \quad$ is the total area of the region

$K_{\text {strata }} \quad$ is the average vertical hydraulic conductivity of the strata in the region

$A_{\text {well }} \quad$ is the cross-sectional area of an individual well acting as a conduit

$K_{\text {well }} \quad$ is the effective vertical hydraulic conductivity of a well acting as a conduit

$i_{\text {well }} \quad$ is the vertical hydraulic gradient for a well acting as a conduit

The value of $i_{\text {well }}$ is expected to be less than that of $i_{\text {regional }}$ since there will be groundwater level drawdown where flow enters the well and mounding where flow exits the well. 
Rearranging Eq. (2) provides an expression for the effective vertical hydraulic conductivity for the groundwater system:

$$
\begin{aligned}
& K_{\text {effective }}=\left\{K_{\text {strata }} i_{\text {regional }}\left[A_{\text {regional }}-\sum_{j=1}^{n}\left(A_{\text {well }}\right)_{j}\right]+\sum_{j=1}^{n}\left(K_{\text {well }} i_{\text {well }} A_{\text {well }}\right)_{j}\right\} \\
& /\left(i_{\text {regional }} A_{\text {regional }}\right)
\end{aligned}
$$

$K_{\text {well }}$ in Eq. (3) is calculated using the Hagen-Poiseuille equation:

$K_{\mathrm{well}}=r^{2} \rho g / 8 \mu$

where:

$r \quad$ is the inner radius of the well casing or screen

$\rho \quad$ is the groundwater density

$g$ is the gravitational acceleration

$\mu$ is the groundwater viscosity

The values used for variables in the in the calculations were as follows:

$i_{\text {regional }} \quad 0.4$ as an example based upon author's experience $A_{\text {total }} \quad 1.0$ mile $^{2}\left(2.6 \mathrm{~km}^{2}\right)$ based upon data presented in Fig. $12 \mathrm{a}$

$K_{\text {regional }} 10^{-5} \mathrm{~cm} / \mathrm{s}$ as an example based upon author's experience

$A_{\text {well }} \quad$ varied based upon the database related to Fig. 12a

$K_{\text {well }} 1.1 \times 10^{6} \mathrm{~cm} / \mathrm{s}$ for a $20-\mathrm{cm}$ diameter well and $2.5 \times 10^{6}$ $\mathrm{cm} / \mathrm{s}$ for a $36-\mathrm{cm}$ diameter well

$i_{\text {well }} \quad 7 \times 10^{-6}$ as an example based upon author's experience (inferred from flows measured in wells)

$n \quad$ varied between 0 and 232 based upon the data presented in Fig. 12a

Importantly, the gradient in the regional strata $\left(i_{\text {regional }}\right)$ results from the hydraulic stresses (pumping and recharge) and the resistance to flow caused by the layered sediments. The value used is consistent with observations in the field by the author. The gradient in the well $\left(i_{\text {well }}\right)$ is much smaller and departs from that in the sediments as a result of head losses across the drawdown cone near the shallow screen, the mound up cone near the deep screen and the well screens themselves. These considerations reduce the hydraulic gradient that drives flow through the well.

A more-detailed approach, possibly similar to Silliman and Higgins (1990), might be applied if the necessary additional information is available and the hydrogeology can be represented as a simple layered system. However, data are often lacking and the goal of performing the calculations presented above is to identify areas where additional investigation and information collection would occur.
Open Access This article is distributed under the terms of the Creative Commons Attribution 4.0 International License (http:// creativecommons.org/licenses/by/4.0/), which permits unrestricted use, distribution, and reproduction in any medium, provided you give appropriate credit to the original author(s) and the source, provide a link to the Creative Commons license, and indicate if changes were made.

\section{References}

Belitz K, Phillips SP, Gronberg JM (1993) Numerical simulation of ground-water flow in the central part of the western San Joaquin Valley, California. US Geol Surv Water Suppl Pap 2396

Bertoldi GL, Johnston RH, Evenson KD (1991) Ground water in the Central Valley, California: a summary report. US Geol Surv Prof Pap 1401-A

Bexfield LM, Jurgens BC (2014) Effects of seasonal operation on the quality of water produced by public supply wells. Ground Water 52(S1):10-24. doi:10.1111/gwat.12174

Bexfield LM, Jurgens BC, Crilley DM, Christenson SC (2012) Hydrogeology, water chemistry, and transport processes in the zone of contribution of a public-supply well in Albuquerque, New Mexico. US Geol Surv Sci Invest Rep 2011-5182

Burow KR, Dubrovsky NM, Shelton JL (2007) Temporal trends in concentrations of DBCP and nitrate in groundwater in the eastern San Joaquin Valley, California, USA. Hydrogeol J 15:991-1007. doi:10. 1007/s10040-006-0148-7

CADWR (1962) Bulletin 74, recommended minimum water well construction and sealing standards for the protection of ground water quality. Preliminary edn. July 1962, State of California, Sacramento, CA

CADWR (1981) Bulletin 74-81, water well standards: State of California. December 1981. http://www.water.ca.gov/pubs/ groundwater/water_well_standards bulletin 74-81/ca_well standards bulletin74-81 1981 .pdf. Accessed 6 July 2016

CADWR (1991) Bulletin 74-90, supplement to bulleting 74-81, California well standards. June 1991. http://www.water.ca.gov/ pubs/groundwater/water_well_standards bulletin_74-90_/ca well_standards_bulletin74-90_1991.pdf. Accessed 6 July 2016

CADWR (2003) California laws for water wells, monitoring wells, cathodic protection wells, geothermal heat exchange wells. March 2003. http://www.water.ca.gov/pubs/groundwater/ california_laws for_water_wells_monitoring wells cathodic protection_wells_geothermal_heat_exchange_wells_2003/ca water_laws_2003.pdf. Accessed 6 July 2016

CADWR (2014) Bulletin 160-14, California water plan update 2013. October 2014. http://www.waterplan.water.ca.gov/cwpu2013/. Accessed 6 July 2016

Church PE, Granato GE (1996) Bias in ground-water data caused by well-bore flow in long-screen wells. Ground Water 34(2):262-273. doi:10.1111/j.1745-6584.1996.tb01886.x

Clark BR, Landon MK, Kauffman LJ, Hornberger GZ (2008) Simulations of ground-water flow, transport, age, and particle tracking near York, Nebraska, for a study of transport of anthropogenic and natural contaminants (TANC) to public supply wells. US Geol Surv Sci Invest Rep 2007-5068

Corcho Alvarado JA, Barbecot F, Purtschert R (2009) Ambient vertical flow in long-screen wells: a case study in the Fontainebleau Sands Aquifer (France). Hydrogeol J 17:425-431. doi:10.1007/s10040008-0383

Davis GH, Lofgren BE, Mack S (1964) Use of ground-water reservoirs for storage of surface water in the San Joaquin Valley California. US Geol Surv Water Suppl Pap 1618 
Dragon K, Gorski J, Marciniak M, Kasztelan D (2009) Use of mathematical modeling to investigate inter-aquifer contamination by organicrich water through an unplugged well (central Wielkopolska, Poland). Hydrogeol J 17:1257-1564. doi:10.1007/s10040-0090432-4

Elci A, Molz FJ, Waldrop WR (2001) Implications of observed and simulated ambient flow in monitoring wells. Ground Water 39(6):853862. doi:10.1111/j.1745-6584.2001.tb02473.x

Faunt CC (ed) (2009) Groundwater availability of the Central Valley Aquifer, California. US Geol Surv Prof Pap 1766

Fetter CW (1994) Applied hydrogeology. Prentice Hall, Englewood Cliffs, NJ

Fogg GE (1986) Groundwater flow and sand body interconnectedness in a thick multiple-aquifer system. Water Resour Res 22(5):1679_ 1694. doi:10.1029/WR022i005p00679

Freeze RA, Cherry JA (1979) Groundwater. Prentice Hall, Englewood Cliffs, NJ

Gass TE, Lehr JH, Heiss HW (1977) Impact of abandoned wells on ground water. US EPA Rep EPA/600/3-77-095, US Environmental Protection Agency, Washington, DC

Halford K (2009) AnalyzeHOLE: an integrated wellbore flow analysis tool. US Geol Surv Surv Tech Methods 4-F2

Halford KJ, Hanson RT (2002) Users guide for the drawdown-limited, multi-node well (MNW) package for the U.S. Geological Survey's modular three-dimensional ground-water flow model, versions MODFLOW-96 and MODFLOW-2000. US Geol Surv Open File Rep 02-293

Halford K, Stamos C, Nishikawa T, Martin P (2010) Arsenic management through well modification and simulation. Ground Water 48(4):526-537. doi:10.1111/j.1745-6584.2009.00670.x

Hanson RT, Zhen L, Faunt CC (2004) Documentation of the Santa Clara Valley regional ground-water/surface-water flow model, Santa Clara County, California. US Geol Surv Sci Invest Rep 2004-5231

Harbaugh AW, Banta ER, Hill MC, McDonald MG (2000) MODFLOW2000 , the US Geological Survey modular ground-water model: user guide to modularization concepts and the ground-water flow process. US Geol Surv Open File Rep 00-92

Hart DJ, Bradbury KR, Feinstein DT (2006) The vertical hydraulic conductivity of an aquitard at two spatial scales. Ground Water 44(2): 201-211. doi:10.1111/j.1745-6584.2005.00125.x

Horn JE, Harter T (2009) Domestic well capture zone and influence of the gravel pack length. Ground Water 47(2):277-286. doi:10.1111/j. 1745-6584.2008.00521.x

Houben GJ, Hauschild S (2011) Numerical modeling of the near-field hydraulics of water wells. Ground Water 49(4):570-575. doi:10. $1111 / j .1745-6584.2010 .00760 . x$

Houben GJ, Treskatis C (2007) Water well rehabilitation and reconstruction. McGraw Hill, New York

Izbicki JA, Christensen AH, Hanson RT, Martin P, Crawford SM, Smith GA (1999) US Geological Survey combined well-bore flow and depth-dependent water sampler. US Geol Surv Fact Sheet 196-99

Izbicki JA, Christensen AH, Newhouse MW, Smith GA, Hanson RT (2005a) Temporal changes in the vertical distribution of flow and chloride in deep wells. Ground Water 43(4):531-544. doi:10.1111/j. 1745-6584.2005.0032.x

Izbicki JA, Christensen AH, Newhouse MW, Aiken GR (2005b) Inorganic, isotopic, and organic composition of high-chloride water from wells in a coastal southern California aquifer. Appl Geochem 20:1496-1517. doi:10.1016/j.apgeochem.2005.04.010

Izbicki JA, Metzger LF, McPherson KR, Everett RR, Bennett GL (2006) Sources of high-chloride water to wells, Eastern San Joaquin Ground-Water Subbasin, California. US Geol Surv Open File Rep 2006-1309

Izbicki JA, Stamos CL, Metzger LF, Halford KJ, Kulp TR, Bennett GL (2008) Source, distribution, and management of arsenic in water from wells, Eastern San Joaquin Ground-Water Subbasin, California. US Geol Surv Open File Rep 2008-1272

Izbicki JA, Wright MT, Seymour WA, McCleskey RB, Fram MS, Belitz $\mathrm{K}$, Esser BK (2015) Cr(VI) occurrence and geochemistry in water from public-supply wells in California. Appl Geochem 63:203-217. doi:10.1016/j.apgeochem.2015.08.007

Jiménez-Martínez J, Arvenda R, Candela L (2011) The role of leaky boreholes in the contamination of a regional confined aquifer: a case study - the campo de Cartagena region, Spain. Water Air Soil Pollut 215:311-327. doi:10.1007/s11270-010-0480-3

Johnson (1961) Dual-aquifer wells pose problems. Johnson National Drillers Journal, January-February 1961

Johnson RL, Clark BR, Landon MK, Kauffman JL, Eberts SM (2011) Modeling the potential impact of seasonal and inactive multi-aquifer wells on contaminant movement to public water-supply wells. J Am Water Resour Assoc 47(3):588-596. doi:10.1111/j.1752-1688.2011. 00526.x

Jurgens BC, Burow KR, Dalgish BA, Shelton JL (2008) Hydrogeology, water chemistry, and factors affecting the transport of contaminants in the zone of contribution of a public-supply well in Modesto, eastern San Joaquin Valley, California. US Geol Surv Sci Invest Rep 2008-5156

Jurgens BC, Fram MS, Belitz K, Burow KR, Landon MK (2010) Effects of groundwater development on uranium: Central Valley, California, USA. Ground Water 48(6):913-928. doi:10.1111/j.1745-6584. 2009.00635.x

Jurgens BC, Bexfield LM, Eberts SM (2014) A ternary age-mixing model to explain contaminant occurrence in a deep supply well. Ground Water 52(S1):25-39. doi:10.1111/gwat.12170

Keys WS (1997) A practical guide to borehole geophysics in environmental investigations. CRC, Boca Raton, FL

Konikow LF, Hornberger GZ (2006) Modeling effects of multinode wells on solute transport. Ground Water 44(5):648-660. doi:10.1111/j. 1745-6584.2006.00231.x

Konikow LF, Hornberger GZ, Halford KJ, Hanson RT (2009) Revised multi-node well (MNW2) package for MODFLOW ground-water flow model. US Geol Surv Tech Methods 6-A30

Lacombe S, Sudicky EA, Frape SK, Unger AJA (1995) Influence of leaky boreholes on cross-formational groundwater flow and contaminant transport. Water Resour Res 31(8):1871-1882. doi:10.1029/ 95WR00661

Landon MK, Clark BR, McMahon PB, McGuire VL, Turco MJ (2008) Hydrogeology, chemical characteristics, and transport processes in the zone of contribution of a public-supply well in York, Nebraska. US Geol Surv Sci Invest Rep 2008-5050

Landon MK, Jurgens BC, Katz BG, Eberts SM, Burow KR, Crandall CA (2009) Depth-dependent sampling to identify short-circuit pathways to public supply wells in multiple aquifer settings in the United States. Hydrogeol J 18(3):577-593. doi:10.1007/s10040-0060148-7

Lu H, Liu T, Chen W, Peng T, Wang C, Tsai M, Liou T (2008) Use of geochemical modeling to evaluate the hydraulic connection of aquifers: a case study from Chianan plain, Taiwan. Hydrogeol J 16:139154. doi:10.1007/s10040-007-0209-6

Ma R, Zheng C, Tonkin M, Zachara JM (2011) Importance of considering intraborehole flow in solute transport modeling under highly dynamic conditions. J Contam Hydrol 123:11-19. doi:10.1016/j. jconhyd.2010.12.001

Mansuy N (1999) Water well rehabilitation: a practical guide to understanding well problems and solutions. Lewis, New York

Mayo AL (2010) Ambient well-bore mixing, aquifer cross-contamination, pumping stress and water quality from long-screened wells: what is sampled and what is not? Hydrogeol J 18:823-837. doi: 10.1007/s10040-009-0568-2

McCombs J, Fiedler AG (1927) Methods of exploring and repairing leaky artesian wells. US Geol Surv Water Suppl Pap 596-A 
McMahon PB, Böhlke JK, Kauffman LJ, Kipp KL, Landon MK, Crandall CA, Burrow KR, Brown CJ (2008) Source and transport controls on the movement of nitrate to public supply wells in selected principal aquifers of the United States. Water Resour Res 44(4): W04401. doi:10.1029/2007WR006252

McMillan LA, Rivett MO, Tellam JH, Dumble P, Sharp H (2014) Influence of vertical flows in wells on groundwater sampling. J Contam Hydrol 169:51-60. doi:10.1016/j.jconhyd.2014.05.005

Mejia A, Cassiraga E, Sahuquillo A (2012) Influence of hydraulic conductivity and wellbore design in the fate and transport of nitrate in multi-aquifer systems. Math Geosci 44:227-238. doi:10.1007/ s11004-012-9388-3

Phillips SP, Belitz K (1991) Calibration of a texture-based model of a ground-water flow system, western San Joaquin Valley, California. Ground Water 29(5):702-715. doi:10.1111/j.1745-6584.1991. tb00562.x

Phillips SP, Green CT, Burow KR, Shelton JL, Rewis DL (2007) Simulation of multiscale ground-water flow in part of northeastern San Joaquin Valley, California. US Geol Surv Sci Invest Rep 20075009

Reilly TE, Franke OL, Bennett GD (1989) Bias in groundwater samples caused by wellbore flow. J Hydraul Eng 115(2):270-276

Santi PM, McCray JE, Martens JL (2006) Investigating crosscontamination of aquifers. Hydrogeol J 14:51-68. doi:10.1007/ s10040-00400403-8

Silliman S, Higgins D (1990) An analytical solution for steady-state flow between aquifers through an open well. Ground Water 28(2):184 190. doi:10.1111/j.1745-6584.1990.tb02245.x

Singleton MJ, Moran JE, Roberts SK, Hillegonds DJ, Esser BK (2010) California GAMA special study: an isotopic and dissolved gas investigation of nitrate source and transport to a public supply well in California's Central Valley, final report for the California State Water Resources Control Board, Rep LLNL-TR-427957. Lawrence Livermore National Laboratory, Livermore, CA

Smith SA, Comeskey AE (2010) Sustainable wells: maintenance, problem prevention, and rehabilitation. CRC, Boca Raton, FL

Sokol D (1963) Position and fluctuations of water level in wells perforated in more than one aquifer. J Geophys Res 68(4):1079-1080
Van Beek CGEM (2012) Cause and prevention of clogging of wells abstracting groundwater from unconsolidated aquifers. IWA, London

Vennard JK, Street RL (1982) Elementary fluid mechanics, 6th edn. Wiley, Chichester, UK

Viers JH, Liptzin D, Rosenstock TS, Jensen VB, Hollander AD, McNally A, King AM, Kourakos G, Lopez EM, De La Mora N, Fryjoff-Hyng A, Dzurella KN, Canada H, Laybourne S, McKenney C, Darby J, Quinn JF, Harter T (2012) Nitrogen sources and loading to groundwater. Technical report 2. In: Addressing nitrate in California's drinking water with a focus on Tulare Lake Basin and Salinas Valley groundwater, Report for the State Water Resources Control Board report to the legislature. Center for Watershed Sciences, University of California, Davis, CA

Vitale SA, Robbins GA (2016) Characterizing groundwater flow in monitoring wells by altering dissolved oxygen. Groundwater Monitor Remed 36(2):59-67. doi:10.1111/gwmr.12157

Wada Y, van Beek LPH, Bierkens MFP (2012) Nonsustainable groundwater sustaining irrigation: a global assessment. Water Resour Res 48(6):W00L06. doi:10.1029/2011WR010562

Welenco (1996) Water and environmental GeopEhysical well logs, volume 1: technical information and data, 8th edn. Welenco, Bakersfield, CA

Williamson AK, Purdic DE, Swain LA (1989) Ground-water flow in the Central Valley of California. US Geol Surv Prof Pap 1401-D

Yager RM, Heywood CE (2014) Simulation of the effects of seasonally varying pumping on intraborehole flow and the vulnerability of public-supply wells to contamination. Ground Water 52(S1):4052. doi:10.1111/gwat.12150

Zheng C, Wang PP (1999) MT3DMS: a modular three-dimensional multispecies transport model for simulation of advection, dispersion, and chemical reactions of contaminants in groundwater systems: documentation and user's guide. US Army Corps Eng Rep SERDP-99-1, US Army Corp of Eng., Washington, DC

Zinn BA, Konikow LF (2007) Effects of intraborehole flow on groundwater age distribution. Hydrogeol J 15(4):633-643. doi:10.1007/ s10040-006-0139-8 